\title{
PHYSICAL AND HYDROLOGIC PROPERTIES OF OUTCROP SAMPLES FROM A NONWELDED TO WELDED TUFF TRANSITION, YUCCA MOUNTAIN, NEVADA
}

by Christopher A. Rautman, Sandia National Laboratories; Lorraine E. Flint, Alan L. Flint, U.S. Geological Survey; and Jonathan D. Istok, Oregon State University

\section{U.S. GEOLOGICAL SURVEY}

Water-Resources Investigations Report 95-4061

Prepared in cooperation with the

NEVADA OPERATIONS OFFICE,

U.S. DEPARTMENT OF ENERGY under

Interagency Agreement DE-Al08-92NV10874,

Contract DE-AC04-94AL85000 


\title{
U.S. DEPARTMENT OF THE INTERIOR \\ BRUCE BABBITT, Secretary
}

\author{
U.S. GEOLOGICAL SURVEY
}

Gordon P. Eaton, Director

The use of trade, product, industry, or firm names is for descriptive purposes only and does not imply endorsement by the U.S. Government.

For additional information write to:

Chief, Earth Science Investigations

Program

Yucca Mountain Project Branch

U.S. Geological Survey

Box 25046, MS 421

Denver Federal Center

Denver, CO 80225
Copies of this report can be purchased from:

U.S. Geological Survey

Earth Science Information Center

Open-File Reports Section

Box 25286, MS 517

Denver Federal Center

Denver, CO 80225 


\section{CONTENTS}

Abstract
Introduction
Geologic overview
Transect stratigraphy
Study methods
Field sampling
Physical and hydrologic properties
Summary
References cited
Appendix

\section{FIGURES}

1. Location of the two-dimensional transect grid and the potential Yucca Mountain repository in southern Nevada

2. Schematic stratigraphic profile of part of the Paintbrush Group (Miocene) nonwelded interval in Solitario Canyon showing position of shardy-base lithologic interval near drill hole USW UZ-6s

3. Variations in porosity with spatial position in the shardy-base unit exposed in Solitario Canyon, Yucca Mountain, Nevada....

4. Variations in saturated hydraulic conductivity with spatial position in the shardy-base unit exposed in Solitario Canyon, Yucca Mountain, Nevada

5. Distribution of values for (a) porosity, (b) bulk density, (c) log sorptivity, and (d) log-saturated hydraulic conductivity for the entire shardy-base unit of the Tiva Canyon Tuff of Miocene age, Yucca Mountain, Nevada.

6. Selected hydrologic properties versus transect elevation, showing vertical control of material properties at Yucca Mountain, Nevada: (a) porosity; (b) bulk density; (c) log sorptivity; (d) logsaturated hydraulic conductivity...

7. Cross-variable correlations between various hydrologic properties measured on samples from the shardy-base unit at Yucca Mountain, Nevada: (a) bulk density as a function of porosity; (b) log sorptivity as a function of porosity; (c) log-saturated hydraulic conductivity as a function of porosity; and (d) $\log$ sorptivity as a function of log-saturated hydraulic conductivity

\section{TABLES}

1. Conceptual comparative stratigraphic columns showing the zonation of units within the Paintbrush Group of Miocene age, Yucca Mountain, Nevada .

2. Summary of transect locations and stratigraphic information, Yucca Mountain, Nevada

3. Summary statistics for samples belonging to the shardy-base unit of the Tiva Canyon Tuff of the Paintbrush Group of Miocene age, Yucca Mountain, Nevada

4. Physical and hydrologic properties of outcrop samples from Yucca Mountain, Nevada, determined by relative-humidity ovendrying. 


$\begin{array}{rll}\text { Multiply } & \text { By } & \text { To obtain } \\ \text { centimeter }(\mathrm{cm}) & & \\ \text { degree Celsius }\left({ }^{\circ} \mathrm{C}\right) & 0.3937 & \text { inch (in) } \\ \text { kilometer }(\mathrm{km}) & \left({ }^{1}\right) & \text { degree Fahrenheit }\left({ }^{\circ} \mathrm{F}\right) \\ \text { megapascals }(\mathrm{MPa}) & 0.6214 & \text { mile (mi) } \\ \text { meter }(\mathrm{m}) & 1.45 \times 10^{2} & \text { pounds per square-inch }\left(\mathrm{lb} / \mathrm{in}^{2}\right) \\ \text { foot (ft) } & \text { pounds per square-inch }\left(\mathrm{lb} / \mathrm{in}^{2}\right) \\ \text { inch (in) }\end{array}$

Degree Celsius $\left({ }^{\circ} \mathrm{C}\right)$ may be converted to degree Fahrenheit $\left({ }^{\circ} \mathrm{F}\right)$ by using the following equation:

$$
{ }^{\circ} \mathrm{F}=9 / 5\left({ }^{\circ} \mathrm{C}\right)+32 \text {. }
$$

The following term and abbreviation also is used in this report:

grams per cubic centimeter $\left(\mathrm{g} / \mathrm{cm}^{3}\right)$

Nevada State Plane Coordinate System: Nevada State Plane Coordinates (in feet) are widely used on the Yucca Mountain Project. These coordinates are for the central zone of Nevada, and are based on a Transverse Mercator projection. The origin of this projection for the central zone of Nevada is latitude $34^{\circ} 45^{\prime} \mathrm{N}$, and the central meridian is at longitude $116^{\circ} 40^{\prime} \mathrm{W}$. Metric conversions of Nevada State Plane Coordinates are distinct from metric coordinates obtained using the 10,000 metre Universal Transverse Mercator grid, Zone II. 


\title{
Physical and Hydrologic Properties of Outcrop Samples from a Nonwelded to Welded Tuff Transition, Yucca Mountain, Nevada
}

\author{
By Christopher A. Rautman, Lorraine E. Flint, Alan L. Flint, and Jonathan D. Istok
}

\begin{abstract}
Quantitative material-property data are needed to describe lateral and vertical spatial variability of physical and hydrologic properties and to model ground-water flow and radionuclide transport at the potential Yucca Mountain nuclearwaste repository site in Nevada. As part of ongoing site characterization studies of Yucca Mountain directed toward this understanding of spatial variability, laboratory measurements of porosity, bulk and particle density, saturated hydraulic conductivity, and sorptivity have been obtained for a set of outcrop samples that form a systematic, twodimensional grid that covers a large exposure of the basal Tiva Canyon Tuff of the Paintbrush Group of Miocene age at Yucca Mountain. The samples form a detailed vertical grid roughly parallel to the transport direction of the parent ash flows, and they exhibit material-property variations in an interval of major lithologic change overlying a potential nuclear-waste repository at Yucca Mountain.
\end{abstract}

The observed changes in hydrologic properties were systematic and consistent with the changes expected for the nonwelded to welded transition at the base of a major ash-flow sequence. Porosity, saturated hydraulic conductivity, and sorptivity decreased upward from the base of the Tiva Canyon Tuff, indicating the progressive compaction of ash-rich volcanic debris and the onset of welding with increased overburden pressure from the accumulating ash-flow sheet. The rate of decrease in the values of these material properties varied with vertical position within the transition interval. In contrast, bulk-density values increased upward, a change that also is consistent with progressive compaction and the onset of welding. Particle-density values remained almost constant throughout the transition interval, proba- bly indicating compositional (chemical) homogeneity.

\section{INTRODUCTION}

Tuffs within the unsaturated zone at Yucca Mountain, located approximately $130 \mathrm{~km}$ northwest of Las Vegas, Nevada, are being investigated as the site of a potential geologic repository for high-level nuclear waste (fig. 1). These studies are sponsored by the U.S. Department of Energy and are being conducted by several Federal agencies and laboratories. As part of these ongoing repository studies, the U.S. Geological Survey and Sandia National Laboratories have conducted a joint investigation during the period 1990 to the present (1994) to obtain values for various hydrologic properties that are needed for analyzing groundwater flow and radionuclide transport. Actual measurements of rock material properties, including hydrologic properties such as those presented in this data report, are needed to develop three-dimensional models of material properties that would be suitable for evaluation through numerical-modeling techniques. Sample data are essential for describing spatial variability of hydrologic properties in the natural rock mass and for evaluating uncertainty in the results of performance modeling.

Rocks at the base of the Tiva Canyon Tuff of the Paintbrush Group of Miocene age exhibit a profound vertical change in hydrologic properties, from properties associated with the overlying densely welded and highly fractured ash-flow tuff to properties characteristic of the underlying nonwelded and unfractured tuffaceous materials. This transition interval represents the first major change in macroscopic lithology — from welded to nonwelded tuff — and in physical properties below the present (1994) topographic surface. This transition interval overlies the potential repository horizon. Precipitation infiltrating downward through Yucca Mountain would pass through this interval of lithologic- and material-property change. The porous and permeable base of the Tiva Canyon Tuff also crops out immediately updip from the potential repository. 


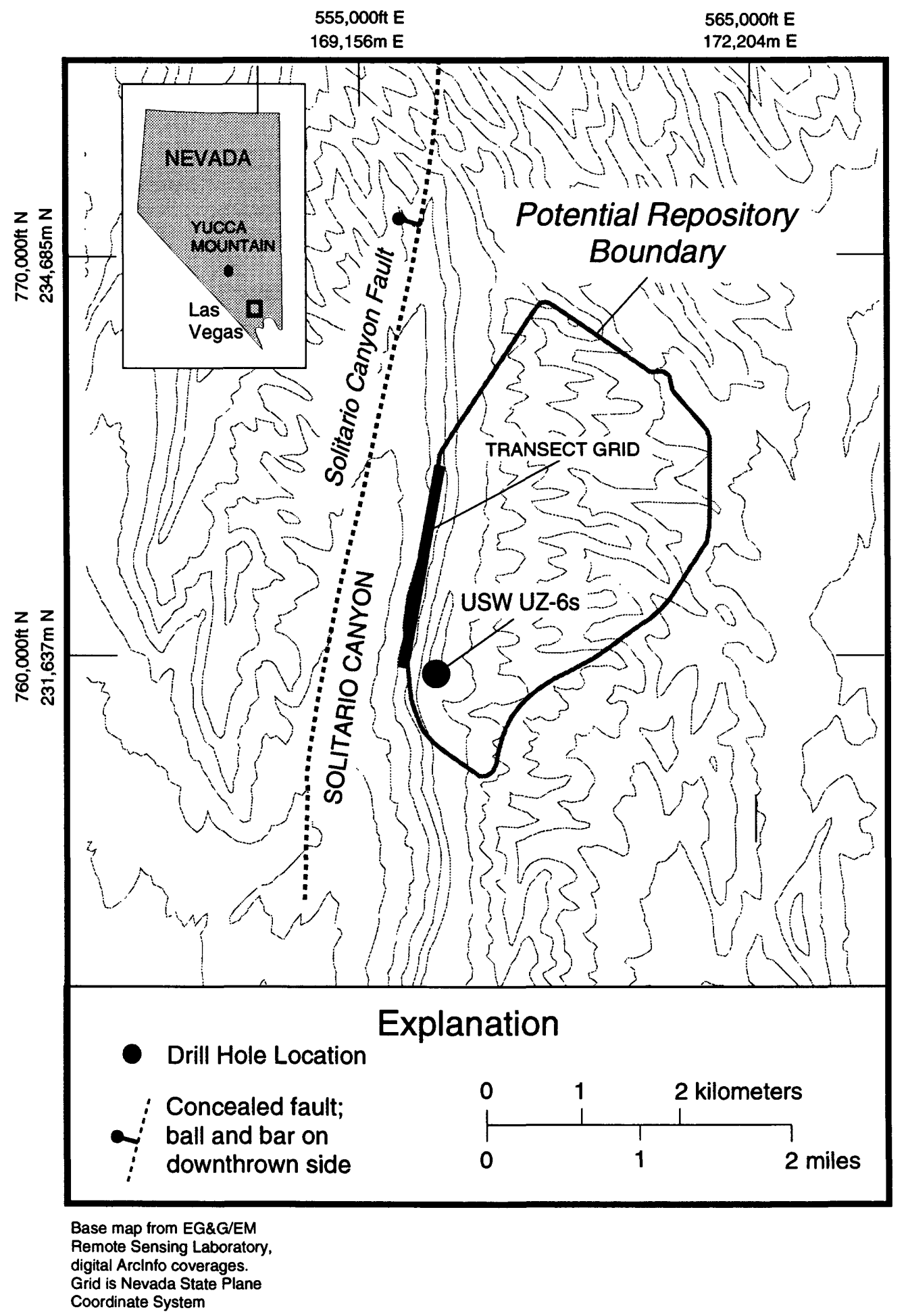

Figure 1. Location of the two-dimensional transect grid and the potential Yucca Mountain repository in southern Nevada. 
As a result, the transition interval also provides a potential pathway for the lateral introduction of infiltrating ground water into Yucca Mountain. Therefore, the basal part of the Tiva Canyon Tuff may have a pronounced effect on the nature and functioning of the unsaturated flow system at Yucca Mountain.

This report presents laboratory measurement data for physical and hydrologic properties of samples obtained from a semiregular, two-dimensional grid covering a large exposure of the basal part of the Tiva Canyon Tuff. Some 330 samples were collected during the early spring of 1992 from 26 individual vertical transects along a 1,300-m north-south exposure. The grid is approximately aligned with the reported southerly direction of ash-flow transport from a caldera source about $6 \mathrm{~km}$ to the north (Carr, 1988). Bulk properties (porosity, bulk density, and particle density) have been determined for relative-humidity oven-dried core samples. Sorptivity and saturated hydraulic conductivity also have been determined for most of the same samples. Additional description and interpretation of the data are presented in Rautman and others (1993) and in Istok and others (1994).

\section{GEOLOGIC OVERVIEW}

Yucca Mountain is underlain by a thick sequence of nonwelded and variably welded ash-flow tuffs intercalated with lesser intervals of air-fall and reworked (bedded) tuffs. This alternating sequence of tuffs has been broken by basin-and-range faulting and forms a series of generally east-dipping fault blocks. The upper part of the volcanic sequence is well exposed by the Solitario Canyon fault along the west face of Yucca Mountain in Solitario Canyon (fig. 1).

The thick, welded intervals of the Tiva Canyon and Topopah Spring Tuffs of the Paintbrush Group of Miocene age were subdivided informally by Scott and Bonk (1984) into a large number of zones of variable lateral extent. This informal zonation has evolved considerably since publication of the Scott and Bonk (1984) geologic map. This evolution has been most pronounced in hydrologic applications. The numerous color-based subdivisions of several of the original zones are not used by some investigators, and the distinction of units that are present mostly outside the immediate repository region have been disregarded. Additional informal geologic names have been developed to identify intervals of distinctive material properties with potentially important hydrologic or engineering-design implications. The informal subdivision of the Paintbrush Group at Yucca Mountain generally resembles the nomenclature used in table 1 in the immediate vicinity of the potential repository
(Rautman and Flint, 1992). The focus of the outcrop sampling described in this report is on the shardy-base unit (unit ccs, table 1) that is present at the base of the Tiva Canyon Tuff.

\section{TRANSECT STRATIGRAPHY}

The base of the shardy-base unit (fig. 2) consists of a pumice-rich air-fall tuff, which overlies a prominent red to orange, oxidized and weathered interval (a paleosol?) developed on an underlying ash-flow deposit, probably equivalent to the Yucca Mountain Tuff, which is mapped at this stratigraphic horizon to the north of the sample grid. These pumiceous materials are tentatively inferred to represent the initial stages of the Claim Canyon eruption and caldera-collapse sequence that ultimately produced the 100 -m-thick Tiva Canyon Tuff (Carr, 1988). The basal pumice-rich air-fall tuff varies in thickness laterally from 0.75 to $2 \mathrm{~m}$. Much of the thickness variation may indicate preexisting topography. Some of the variation in thickness may also indicate later erosion, because some exposures have been reworked, indicating minor breaks in volcanic activity preceding eruption of the main phase of the Tiva Canyon Tuff. A weakly developed, slightly iron-stained interval at the top of the pumice-rich airfall tuff may indicate incipient development of a weathering profile during a brief period of quiescence.

The pumice-rich air-fall tuff is overlain by 7.5 to $12 \mathrm{~m}$ (average thickness $9 \mathrm{~m}$ ) of ash-flows that compose the bulk of the shardy-base unit (fig. 2). Two subunits seem to be present. The lower ash flow is nonwelded, poorly sorted, and varies in thickness from less than 2.5 to more than $6 \mathrm{~m}$. A 0.5 -m-thick interval at the base of the lower ash flow may locally contain large (as large as $10 \mathrm{~cm}$ ) light-colored pumice fragments that are similar in composition and in color to the ash matrix and may be difficult to distinguish visually from the remainder of the ash flow. The upper ash flow varies from 2 to $6 \mathrm{~m}$ in thickness and changes from nonwelded at the base to densely welded at a gradational upper contact with the overlying columnar unit (fig. 2).

Distinctive yellow and less-common black, glass shards, easily visible under a hand lens, are characteristic of the entire shardy-base microstratigraphic unit. The gradational top of the shardy-base unit is characterized by the loss of macroscopically visible glass shards and the presence of increased welding, devitrification, and vapor-phase alteration. Locally, in the southern part of the outcrop, the shardy-base unit is overlain by a prominent, dark-gray, vertically jointed black vitrophyre. The vitrophyre seems to rise stratigraphically to the north in relationship to the top of the 
Table 1. Conceptual comparative stratigraphic columns showing the zonation of units within the Paintbrush Group of Miocene age, Yucca Mountain, Nevada

[Abbreviations: Mtn. - Mountain, Cyn. - Canyon, Mbr. - Member. Proposed zonation of Buesch and others, Sequential letter codes: Tpc - Tiva Canyon, Tpt - Topopah Spring; $r$ - crystal-rich, p - crystal poor; $\mathrm{u}$ - upper, 1 - lower; $\mathbf{m}$ - middle; 1 - lithophysal, $\mathbf{n}$ nonlithophysal, v- vitric. Thermal/Mechanical Units, Sequential letter codes: TC - Tiva Canyon;.PT - Paintbrush; TS - Topopah Spring; CH - Calico Hills; $\mathbf{w}$ - welded; $n$ - nonwelded]

\begin{tabular}{|c|c|c|c|c|c|c|}
\hline \multicolumn{2}{|c|}{$\begin{array}{l}\text { Geologic Unit } \\
\text { (from Sawyer and } \\
\text { others, 1994) }\end{array}$} & \multicolumn{3}{|c|}{$\begin{array}{c}\text { Hydrologic zonation } \\
\text { (modified after } \\
\text { Scott and Bonk, 1984) }\end{array}$} & $\begin{array}{c}\text { Proposed } \\
\text { zonation of } \\
\text { Buesch and others } \\
\text { (USGS, written comm., 1994) }\end{array}$ & $\begin{array}{l}\text { Thermal/mechanical } \\
\text { unit } \\
\text { (Ortiz and others, 1985) }\end{array}$ \\
\hline \multirow{24}{*}{ 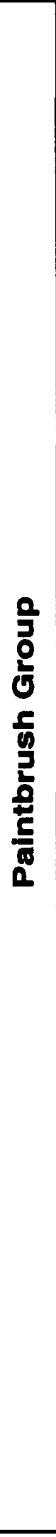 } & \multirow{10}{*}{$\begin{array}{l}\text { Tiva } \\
\text { Canyon } \\
\text { Tuff }\end{array}$} & \multirow{24}{*}{  } & \multirow{10}{*}{$\begin{array}{l}\text { Tiva } \\
\text { Canyon } \\
\text { Member }\end{array}$} & cer - caprock & Tpen & \multirow{8}{*}{$\mathrm{TCw}$} \\
\hline & & & & cuc - upper cliff & Tpcrn & \\
\hline & & & & \multirow{2}{*}{ cul - upper lithophysal } & Tpcrl & \\
\hline & & & & & Tpcpul & \\
\hline & & & & cks - clinkstone & Tpcpmn & \\
\hline & & & & cll - lower lithophysal & Tpcpll & \\
\hline & & & & ch - hackly & Tpcpinh & \\
\hline & & & & cc-columnar & $\begin{array}{l}\text { Tpcolnc } \\
\text { Tpcpv3 }\end{array}$ & \\
\hline & & & & ccs - shardy base & Tpcpv2 & \\
\hline & & & & & Tpcpv1 & \\
\hline & Yucca Mtn. Tuff & & Yucca Mtn. Mbr. & not subdivided & or this remort & \\
\hline & Pah Cyn. Tutf & & Pah Cyn. Mbr. & & & PIn \\
\hline & \multirow{12}{*}{$\begin{array}{l}\text { Topopah } \\
\text { Spring } \\
\text { Tuff }\end{array}$} & & \multirow{12}{*}{$\begin{array}{l}\text { Topopah } \\
\text { Spring } \\
\text { Member }\end{array}$} & unper nopumelded & Tptrv3 & \\
\hline & & & & 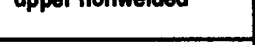 & Tptrv2 & \\
\hline & & & & tc- caprock & Tptrv1 & \multirow{4}{*}{ TSw1 } \\
\hline & & & & tr - rounded & Tptrn & \\
\hline & & & & \multirow{2}{*}{ tul - upper lithophysal } & Tptrl & \\
\hline & & & & & Tptpul & \\
\hline & & & & tn-nonlithophysal & Tptpmn & \multirow{3}{*}{ TSw2 } \\
\hline & & & & th - lower lithophysal & Tptpll & \\
\hline & & & & $\mathrm{tm} \cdot \mathrm{mottled}$ & Tptpln & \\
\hline & & & & tv - basal vitrophyre & Tptpv3 & TSw3 \\
\hline & & & & \multirow{2}{*}{ nonwelded base } & Tptpv2 & \multirow[b]{3}{*}{ CHn1 } \\
\hline & & & & & Tptpv1 & \\
\hline & $\begin{array}{l}\text { alico Hills } \\
\text { rmation }\end{array}$ & $\begin{array}{l}\text { T } \\
\text { B } \\
\text { C }\end{array}$ & $\begin{array}{l}\text { uffaceous } \\
\text { eds of } \\
\text { alico Hills }\end{array}$ & not subdivided & for this report & \\
\hline
\end{tabular}




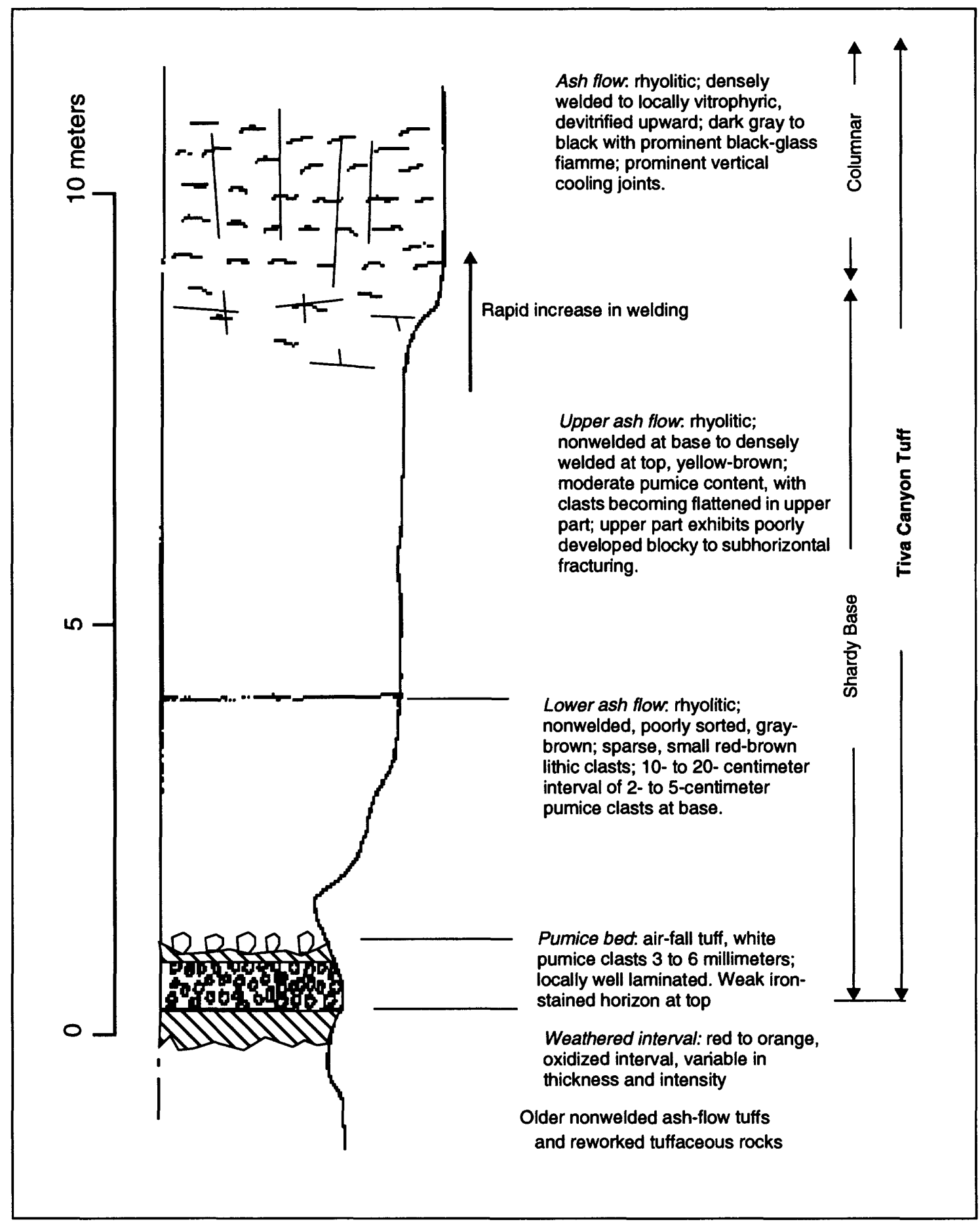

Figure 2. Schematic stratigraphic profile of part of the Paintbrush Group (Miocene) nonwelded interval in Solitario Canyon showing position of shardy-base lithologic interval near drill hole USW UZ-6s. 
shardy base, beginning slightly to the north of drill hole USW UZ-6s. The shardy-base unit is gradationally overlain by devitrified welded tuff to the north. The upper limit of the shardy-base unit, as the term is used in this report, occurs where the rock becomes black vitrophyre or devitrified, densely welded tuff. A distinct change in the style of jointing and fracturing also marks the contact with the overlying columnar unit. A poorly defined pattern of blocky, subhorizontal fractures within the upper part of the shardy-base unit is replaced at this gradational contact by the distinctive vertical cooling joints, from which the overlying columnar unit (table 1) derives its name (Scott and Bonk, 1984; these authors include the vitrophyre within their columnar unit). These flows, together with the overlying welded and devitrified rocks, represent products of the ongoing, if episodic, eruption and collapse of the Claim Canyon caldera (Carr, 1988).

\section{STUDY METHODS}

\section{Field Sampling}

Approximately 330 core samples, nominally $2.5 \mathrm{~cm}$ in diameter and 4 to $10 \mathrm{~cm}$ in length, were collected from 26 vertical transects along the north-southtrending outcrop of the basal Tiva Canyon Tuff using a gasoline-powered, portable core drill and clear tap water [Nevada Test Site (NTS) well J-13] as a lubricant. The sample locations were measured in the field as the stratigraphic distance above the base of the basal air-fall pumice bed (fig. 2). The thickness of the shardy-base unit changes along the transect grid from 7.5 to $12 \mathrm{~m}$, and outcrops are variable in quality. Stratigraphic spacings between samples were measured using a 5-foot (about $1.5 \mathrm{~m}$ ) Jacob's staff and an Abney level, supplemented by visual interpolation and a steel measuring tape. The (stratigraphically) vertical spacing between samples varied from 0.1 to $3.5 \mathrm{~m}$ and averaged $0.76 \mathrm{~m}$. The number of samples per transect ranged from 10 to 17 .

The north-south location of each transect was measured compared to the location of an earlier transect (Flint and others, 1995) in the vicinity of drill hole USW UZ-6s located on the crest of Yucca Mountain (fig. 1) at Nevada State Plane Coordinates (defined in feet) $759,909.3 \mathrm{~N}, 558,050.4 \mathrm{E}$ (Fenix and Scisson, Inc., 1987) (equivalent to $231,609.1 \mathrm{~N}, 170,085.5 \mathrm{E}$, in meters). East-west locations were not recovered. Separations between transects were measured using a Topofil $^{\mathrm{TM}}$ commercial string-measuring device at the upper terminus of each transect (at the base of the columnar unit). Spacings between individual transects averaged $55 \mathrm{~m}$. Transects were generally closer together in the southern part of the outcrop (as close as $19 \mathrm{~m}$ ) and were more widely separated (as much as $200 \mathrm{~m}$ ) in the northern part, as the quality of the outcrop decreased because of northward convergence between the floor of Solitario Canyon and the outcrop trace of the shardy-base unit. Relative horizontal variation of sample locations along a specific vertical transect was assumed to be negligible, given the distances between transects. This scheme of locating samples by their vertical position within a transect produced an $x-z$ (horizontal distance-elevation) grid approximately along the line indicated in figure 1. A summary of transect-location data and various relevant stratigraphic information is listed in table 2 .

\section{Laboratory Analyses}

In the laboratory, the core plugs were trimmed using a small diamond saw to approximate rightcircular cylinders for material-properties testing. Porosity $(\phi$, in cubic centimeters per cubic centimeter and expressed as a decimal fraction for simplicity), bulk density ( $\rho_{b}$, in grams per cubic centimeter), and particle density ( $\rho_{p}$, in grams per cubic centimeter) were determined using gravimetry and Archimedes' principle to determine sample volume. There are two major departures from the classical application (ASTM, 1977) of this technique. First, the samples were initially saturated with carbon dioxide gas by introducing the gas into an evacuated bell jar containing the samples; this process, which was repeated three times, prevents air entrapment in small internal pores of densely welded tuff samples because the $\mathrm{CO}_{2}$ is soluble in water. The samples then were saturated with degassed distilled water under a vacuum. Scoping studies indicated that saturated weights did not change meaningfully following a single iteration of this vacuum-saturation process, even with the addition of a pressure-saturation step. Second, samples were dried in a relative-humidity ( $\mathrm{RH}$ )-controlled oven at $60^{\circ} \mathrm{C}$ and 45 percent RH (Bush and Jenkins, 1970), rather than at $105^{\circ} \mathrm{C}$ and associated ambient RH (per ASTM, 1977). Soeder and others (1991) advocated the use of this lower-temperature/humidified technique, not only to preserve water present in the crystal structure of any clays and hydrated minerals (such as zeolites) present, but also to retain water loosely bound to grain surfaces that is not available to participate in unsaturated flow. Particle density, as used in this report, is similar to the more commonly reported grain density. However, because particle density is a property computationally 
Table 2. Summary of transect locations and stratigraphic information, Yucca Mountain, Nevada [All distances in meters. Values may not add exactly because of unit conversions and rounding.]

\begin{tabular}{|c|c|c|c|c|c|}
\hline $\begin{array}{c}\text { Transect } \\
\text { identification }\end{array}$ & $\begin{array}{l}\text { Horizontal } \\
\text { distance north } \\
\text { from USW } \\
\text { UZ-6 transect }\end{array}$ & $\begin{array}{c}\text { Thickness } \\
\text { of basal } \\
\text { pumice- } \\
\text { rich air-fall } \\
\text { tuff }\end{array}$ & $\begin{array}{c}\text { Thickness } \\
\text { of lower } \\
\text { ash flow }\end{array}$ & $\begin{array}{c}\text { Thickness } \\
\text { of upper } \\
\text { ash flow }\end{array}$ & $\begin{array}{c}\text { Total } \\
\text { thickness }\end{array}$ \\
\hline SB-1 & 19.20 & 0.99 & 3.12 & 4.39 & 8.53 \\
\hline SB-2 & 49.68 & 0.76 & 3.66 & 4.65 & 9.07 \\
\hline SB-3 & 72.23 & 1.37 & 3.20 & 4.88 & 9.45 \\
\hline SB-4 & 121.00 & 0.91 & 3.66 & 4.88 & 9.45 \\
\hline SB-5 & 142.94 & 0.99 & 3.43 & 4.95 & 9.37 \\
\hline SB-6 & 177.38 & 1.83 & 2.82 & 4.50 & 9.14 \\
\hline SB-7 & 201.46 & 0.91 & 3.66 & 3.58 & 8.15 \\
\hline SB-8 & 233.77 & 1.07 & 2.51 & 4.04 & 7.62 \\
\hline SB-9 & 261.20 & 0.76 & 3.43 & 4.88 & 9.07 \\
\hline SB-10 & 288.02 & 0.99 & 4.04 & 3.43 & 8.46 \\
\hline SB-11 & 328.86 & 1.52 & 6.02 & 4.72 & 12.27 \\
\hline SB-12 & 366.66 & 2.44 & 3.35 & 2.13 & 7.92 \\
\hline SB-13 & 431.27 & 0.91 & 4.11 & 3.35 & 8.38 \\
\hline SB-14 & 458.70 & 0.84 & 4.42 & 3.20 & 8.46 \\
\hline SB-15 & 484.30 & 0.76 & 4.27 & 4.42 & 9.45 \\
\hline SB-16 & 563.24 & 1.52 & 5.33 & 4.11 & 10.97 \\
\hline SB-17 & 618.10 & 1.37 & 3.12 & 5.71 & 10.21 \\
\hline SB-18 & 648.28 & 1.22 & 3.73 & 4.95 & 9.91 \\
\hline SB-19 & 702.83 & 1.37 & 3.43 & 5.11 & 9.91 \\
\hline SB-20 & 742.15 & 1.07 & 2.36 & 5.56 & 8.99 \\
\hline SB-21 & 833.59 & 1.07 & 2.59 & 5.94 & 9.60 \\
\hline SB-22 & 918.93 & 1.07 & 3.96 & 3.81 & 8.84 \\
\hline SB-23 & 995.12 & 1.14 & 4.65 & 4.42 & 10.21 \\
\hline SB-24 & $1,092.65$ & 1.22 & 4.72 & 3.89 & 9.83 \\
\hline SB-25 & $1,293.81$ & 1.22 & 5.03 & 3.66 & 9.91 \\
\hline SB-26 & $1,321.24$ & 1.22 & 5.03 & 4.50 & 10.74 \\
\hline
\end{tabular}


derived from intact core samples, totally encapsulated void space, which was inaccessible to water flow, was not considered. Particle density is almost invariably lower than a grain-density determination obtained by crushing the rock and measuring the total volume of solid material. Particle density will approach grain density for rocks that have minimal totally encapsulated pore space.

Originally, the bulk-property measurements were to be repeated after more conventional drying of the samples at $105^{\circ} \mathrm{C}$ for comparison with other reported data (ASTM, 1977). However, physical disaggregation of the least-consolidated nonwelded samples through continued handling compromised sample integrity to the point that the validity of the comparison would have been questionable. Therefore, bulkproperty measurements corresponding to oven drying at $105^{\circ} \mathrm{C}$ have not been obtained.

Sample weights were reduced to the desired bulk properties as follows:

$$
\begin{gathered}
\rho_{b}=\frac{\text { dry weight }}{\text { bulk volume }}, \\
\phi=\frac{\text { saturated weight }- \text { dry weight }}{\text { bulk volume } \times \rho_{w}} \text {, and } \\
\rho_{p}=\frac{\text { dry weight }}{\text { bulk volume }- \text { pore volume }} \text {, where } \\
\text { pore volume }=\frac{\text { (saturated weight }- \text { dry weight) }}{\rho_{w}},
\end{gathered}
$$

$\rho_{w}$ is the temperature-adjusted density of water (in grams per cubic centimeter). Bulk volume is simply the mass of the saturated sample submerged in water (Archimedes' principle).

Sorptivity was determined for all core samples that withstood the mechanical processing of the bulkproperty measurements. Sorptivity represents flow under unsaturated conditions, describing the rate of uptake of water by a porous media without gravitational effects (Philip, 1957). The relation is given by:

$$
I=S \sqrt{t}+A t
$$

where $I$ is imbibition, $S$ is sorptivity, $t$ is time, and $A$ is a constant. For the early part of imbibition, At was assumed to be negligible (Talsma, 1969) and $I=S \sqrt{t}$, where $I$ is the quantity of water (in cubic centimeters) imbibed per unit area (in square centimeters); $S$ is expressed in centimeters per $\sqrt{\text { time }}$; and $t$ is measured in seconds. For convenience, sorptivity is generally presented as $\log S$ (base 10) throughout this report.

For this experiment, the bottom of an acrylic box was lined with a towel that was kept saturated with tap water from NTS well J-13 using a constant-head Mariotte system. Relative-humidity-dried core samples were weighed, placed on the saturated surface, and periodically reweighed to determine the cumulative weight of water that imbibed as a function of time (Flint and others, 1994). The cross-sectional area of each sample was determined by measuring the diameter using a micrometer. At least three measurements were made in different locations on each sample and the results were averaged. Sorptivity was determined as the slope of a line fit through the data that were plotted as $I$ versus $\sqrt{ } t$.

Saturated hydraulic conductivity, $K_{s}$, in meters per second [generally presented as $\log K_{s}$ (base 10) throughout this report], was determined for all physically intact core samples. Saturated hydraulic conductivity values were measured using a constant-head method, which is described as follows. After imbibition measurements, the core samples were resaturated with tap water using the vacuum-evacuation $/ \mathrm{CO}_{2}-$ flooding technique. Each sample was encased inside heat-shrink tubing lined with a water-resistant sealant to preserve sample integrity during handling and measurements. Care was taken to apply the minimum amount of heat required to shrink the tubing and to obtain a water-tight seal. The encased samples were again resaturated with tap water with the same vacuum-evacuation/ $/ \mathrm{CO}_{2}$-flooding technique. To measure saturated hydraulic conductivity, an encased core sample was inserted into a length of vinyl tubing $(2.5-\mathrm{cm}$ inside diameter); hose clamps were used to secure the sample. One end of the tubing was attached to a reservoir that maintained a constant water level $1.5 \mathrm{~m}$ above the end of the sample. The outflow end of the core sample was kept saturated at all times. The volume of tap water flowing through a core sample for 72 hours was collected, measured, and used to compute saturated hydraulic conductivity according to the equation: 


$$
K_{s}=\frac{Q}{A} \cdot \frac{\Delta H}{L}
$$

where $Q$ is the quantity of water flowing through the sample per unit time (in cubic centimeters per second), $A$ is the cross-sectional area of the sample core plug (in square centimeters), $\Delta H$ is the change in total head across the sample (in centimeters), and $L$ is the coreplug length (in centimeters).

Those few samples for which a head in excess of $1.5 \mathrm{~m}$ was needed to produce measurable flow (from one to three of the more-welded samples from each transect) were tested in a pressure permeameter to impose a differential hydraulic head of as much as $60 \mathrm{~m}$ across the sample. These samples (and their heatshrink tubing) were encased in heavy vinyl tubing and placed in a chamber that produced a hydraulic confining pressure $(0.41-0.55 \mathrm{MPa})$, slightly exceeding the gradient across the sample, and that prevented flow down the sides of the sample. Confining pressures of this magnitude did not affect the permeability of the rock, particularly because confining pressures were applied only to welded samples that had compressive strengths on the order of $100 \mathrm{MPa}$ (Nimick and Schwartz, 1987). A separate system provided J-13 tap water under pressure for flow through the sample. Effluent was weighed on a top-loading balance, as the water left the sample, and the mass was recorded as a function of time. Saturated hydraulic conductivity was computed using Darcy's law (eq. 6) with measured sample lengths, cross-sectional areas and the appropriate steady-state flow measurements.

\section{PHYSICAL AND HYDROLOGIC PROPERTIES}

The laboratory measurements of porosity, an important framework hydrologic property from the transect samples, are presented in semiquantitative graphical form in figure 3. A corresponding presentation for saturated hydraulic conductivity is presented in figure 3. Although these graphs are only an approximate representation, they simultaneously portray the density and variability of sample coverage, the variation in stratigraphic thicknesses, and some of the systematic differences in material properties with spatial position. The visual impression is that porosity values (fig. 3) are markedly higher at the base of the unit (in excess of 60 percent), and that they decrease progressively upward. This upward decrease in porosity corresponds to progressive upward compaction and incipient welding, which occurs at the bottom of all welded-tuff sequences. A similar progressive decrease is observed in values for saturated hydraulic conductivity (fig. 3). Values for porosity and for saturated hydraulic conductivity seem to be semiquantitatively equal at equivalent stratigraphic levels within each unit.

The actual, quantitative values of all bulk and hydrologic-flow properties measured for the transect samples are listed in table 4 in the appendix at the back of this report. A statistical summary of these data for samples belonging to the shardy-base unit and its subdivisions is presented in table 3 . These same data are presented in histogram format in figure 5.

The statistical summary values from table 3 confirm the visual impressions derived from figures 3 and 4. The mean porosity value in the basal pumice-rich air-fall tuff is more than $\mathbf{5 2}$ percent, decreasing to 40 percent in the lower ash-flow tuff and decreasing again to 20 percent in the upper ash-flow tuff. Similar trends in the maximum and minimum measured porosity values are indicated. The differences in the complete distribution of values is emphasized in the histograms in figure 5, and the visual impressions of the histograms are confirmed by the numerical statistics in table. For example, the coefficient of variation for porosity is noticeably larger in the upper ash-flow tuff ( 51 percent, compared to 12 percent in the other units), verifying the field observation that most of the gradation in welding occurs within this subzone (see also fig. 2). Mean bulk density values increased markedly upward from 1.13 to $1.89 \mathrm{~g} / \mathrm{cm}^{3}$ (table 3 ), varying inversely with porosity, and again indicating progressive physical compaction and welding of the tuff. For porosity and bulk density, the distribution of values changes most between the basal pumice-rich air-fall tuff and the two overlying ash-flow units, as is indicated by the comparative histograms (fig. 5). This contrast is attributed to differences in emplacement mechanics between the shower-like rain of well-sorted pyroclastic fragments from an airborne eruption cloud versus the concurrent, mass accumulation of a poorly sorted mix of volcanic debris from a density current produced by eruption-column collapse.

In contrast to the behavior of the other bulk properties, mean particle densities were almost constant through the profile at slightly greater than $2.3 \mathrm{~g} / \mathrm{cm}^{3}$ (table 3 ). This consistency may reflect the uniformity of composition of the rhyolitic ash-flow material. Interestingly, the maximum measured particle density changed the most, increasing from a low of $2.39 \mathrm{~g} / \mathrm{cm}^{3}$ in the lower pumice-rich air-fall tuff to $2.49 \mathrm{~g} / \mathrm{cm}^{3}$ and then to $2.57 \mathrm{~g} / \mathrm{cm}^{3}$ in the upper ash-flow subunit (table 3). This variation may indicate the expected, progressive upward elimination of intact gas bubbles in 


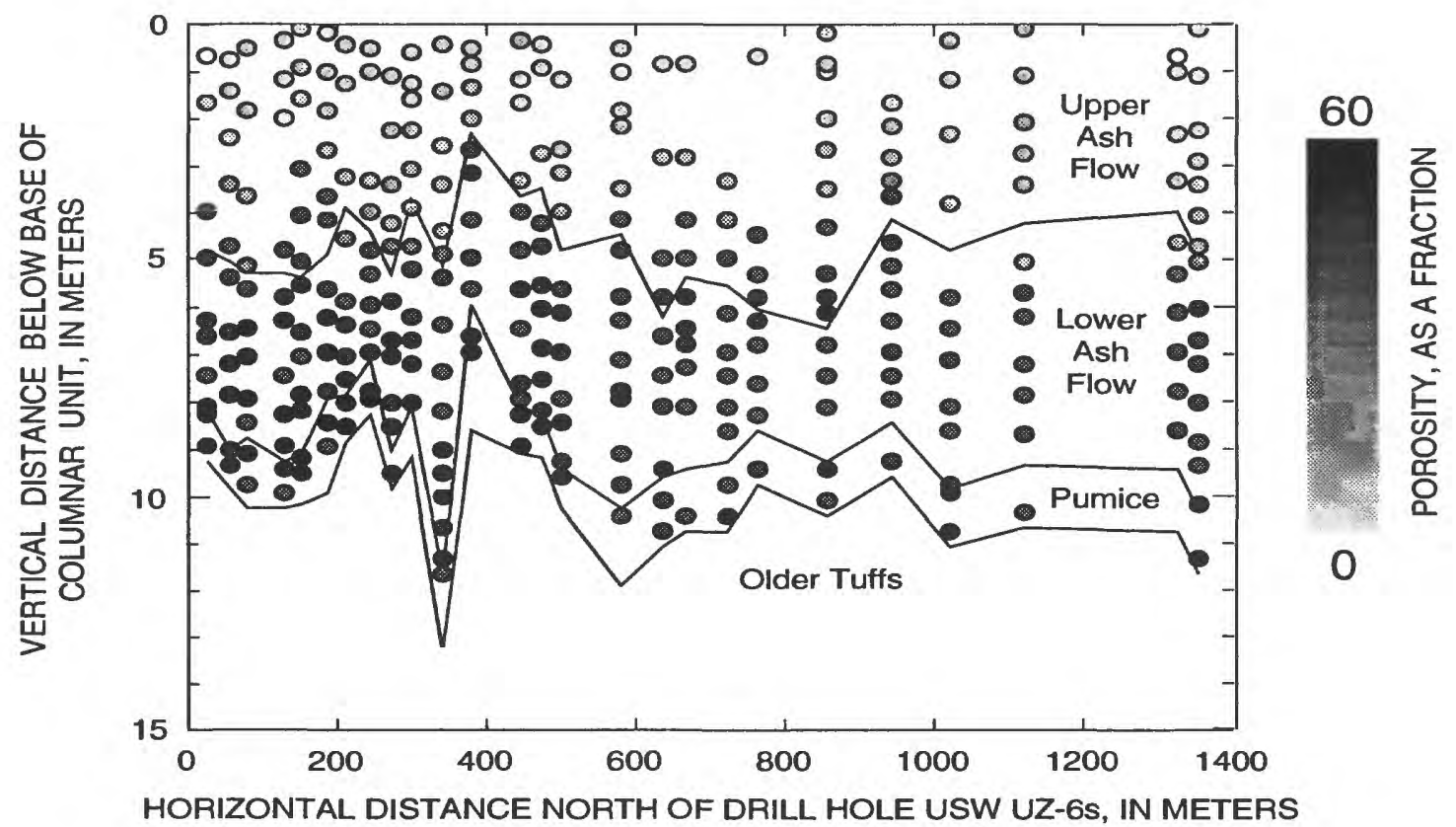

Figure 3. Variations in porosity with spatial position in the shardy-base unit exposed in Solitario Canyon, Yucca Mountain, Nevada. Positions of dots indicate the approximate locations of samples below the lower contact of the columnar unit. Dots are gray-scale coded in proportion to the porosity value they represent. Contacts of the three subunits identified in the field are shown by lines. 
$\mathrm{S} \quad \mathrm{N}$

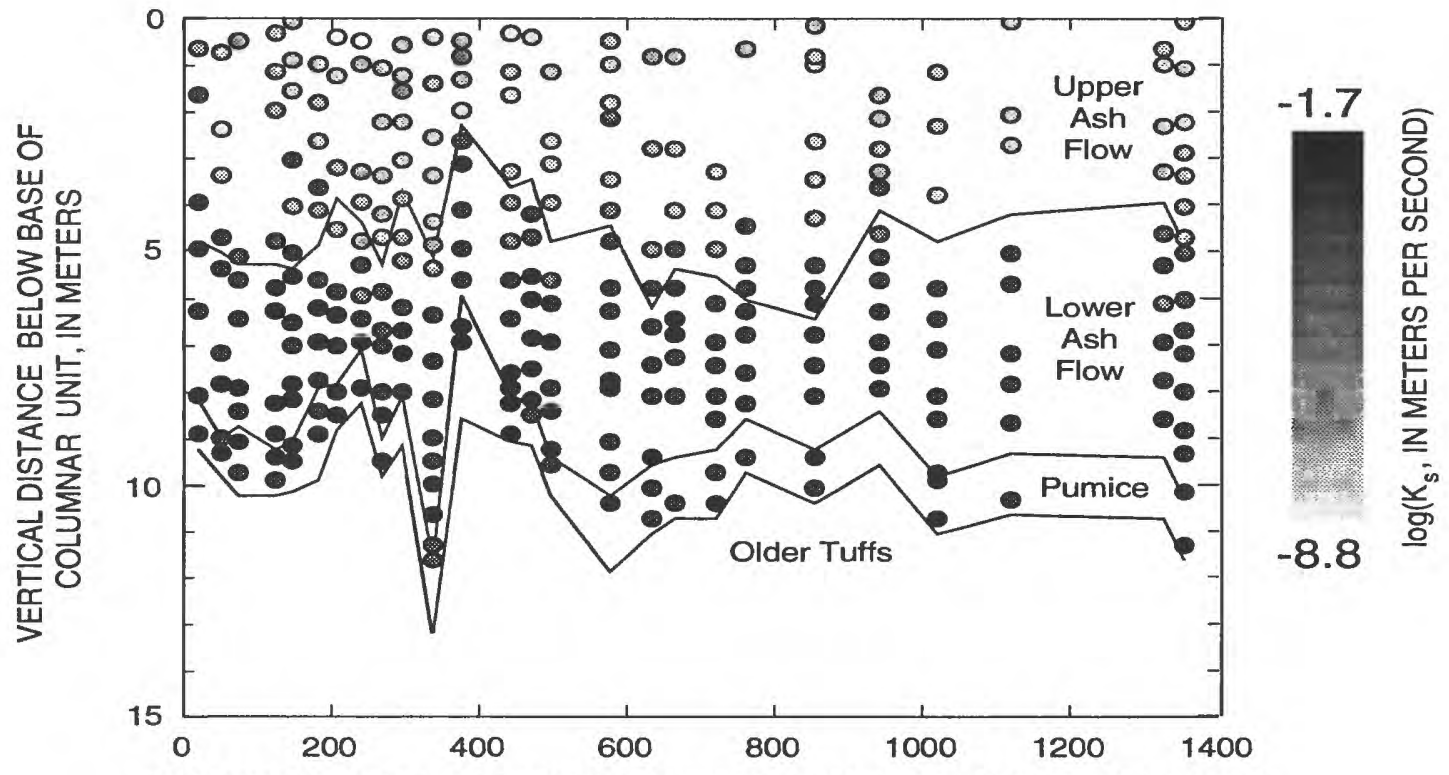

HORIZONTAL DISTANCE NORTH OF DRILL HOLE USW UZ-6s, IN METERS

Figure 4. Variations in saturated hydraulic conductivity with spatial position in the shardy-base unit exposed in Solitario Canyon, Yucca Mountain, Nevada. Positions of dots indicate the approximate locations of samples below the lower contact of the columnar unit. Dots are gray-scale coded in proportion to the saturated hydraulic-conductivity value they represent. Contacts of the three subunits identified in the field are shown by lines. 
Table 3. Summary statistics for samples belonging to the shardy-base unit of the Tiva Canyon Tuff of the Paintbrush Group of Miocene age, Yucca Mountain, Nevada

[C.V., coefficient of variation, a standardized measure of variability, is defined as the standard deviation divided by the mean, and generally is expressed in percent; $N$, number of samples. $\log (S)$, logarithm of sorptivity; $\log \left(K_{s}\right)$, logarithm of saturated hydraulic conductivity]

\begin{tabular}{|c|c|c|c|c|c|}
\hline $\begin{array}{l}\text { Statiatical } \\
\text { measure }\end{array}$ & $\begin{array}{l}\text { Porosity } \\
\text { (fraction) }\end{array}$ & $\begin{array}{l}\text { Bulk dengity } \\
(\mathrm{g} / \mathrm{cm})^{3}\end{array}$ & $\begin{array}{l}\text { Particle degnsity } \\
\left(\mathrm{g} / \mathrm{cm}^{3}\right)\end{array}$ & $\frac{\log (s)}{(\mathrm{cm} / \sqrt{\sec })}$ & $\begin{array}{l}\log \left(K_{d}\right) \\
(\mathrm{m} / \mathrm{eec})\end{array}$ \\
\hline \multicolumn{6}{|c|}{ Upper Ash-Flow Subunit } \\
\hline Minimum & 0.056 & 1.30 & 2.21 & -5.896 & -8.839 \\
\hline Maximum & 0.445 & 2.27 & 2.57 & -3.396 & -3.133 \\
\hline Mean & 0.195 & 1.89 & 2.35 & -5.082 & -6.728 \\
\hline Variance & 0.0099 & 0.0589 & 0.0016 & 0.2631 & 1.5789 \\
\hline c.v. & 51 & 13 & 2 & 10 & 19 \\
\hline $\mathbf{N}$ & 130 & 130 & 130 & 122 & 120 \\
\hline \multicolumn{6}{|c|}{ Lower Ash-Flow Subunit } \\
\hline Minimum & 0.201 & 1.13 & 2.23 & -5.225 & -6.870 \\
\hline Maximum & 0.546 & 1.87 & 2.49 & -2.907 & -2.154 \\
\hline Mean & 0.403 & 1.38 & 2.31 & -3.831 & -3.826 \\
\hline Variance & 0.0023 & 0.0123 & 0.0015 & 0.2296 & 1.0075 \\
\hline c.v. & 12 & 8 & 2 & 13 & 26 \\
\hline $\mathrm{N}$ & 140 & 140 & 140 & 133 & 133 \\
\hline \multicolumn{6}{|c|}{ Basel Pumlco-Rich Air-Fall Tuff Subunit } \\
\hline Minimum & 0.341 & 0.93 & 2.31 & -4.063 & -4.511 \\
\hline Maximum & 0.603 & 1.54 & 2.39 & -2.986 & -1.607 \\
\hline Mean & 0.520 & 1.13 & 2.35 & -3.452 & -2.862 \\
\hline Variance & 0.0042 & 0.0249 & 0.0005 & 0.0699 & 0.5030 \\
\hline c.v. & 12 & 14 & 1 & 8 & 25 \\
\hline $\mathbf{N}$ & 36 & 36 & 36 & 35 & 33 \\
\hline \multicolumn{6}{|c|}{ Entire Shardy-Base Unit } \\
\hline Minimum & 0.056 & 0.93 & 2.21 & -5.896 & -8.839 \\
\hline Maximum & 0.603 & 2.27 & 2.57 & -2.907 & -1.607 \\
\hline Mean & 0.329 & 1.56 & 2.33 & -4.312 & -4.933 \\
\hline Variance & 0.0202 & 0.1170 & 0.0018 & 0.670 & 3.6077 \\
\hline C.V. & 43 & 22 & 2 & 19 & 39 \\
\hline $\mathrm{N}$ & 306 & 306 & 306 & 290 & 286 \\
\hline
\end{tabular}



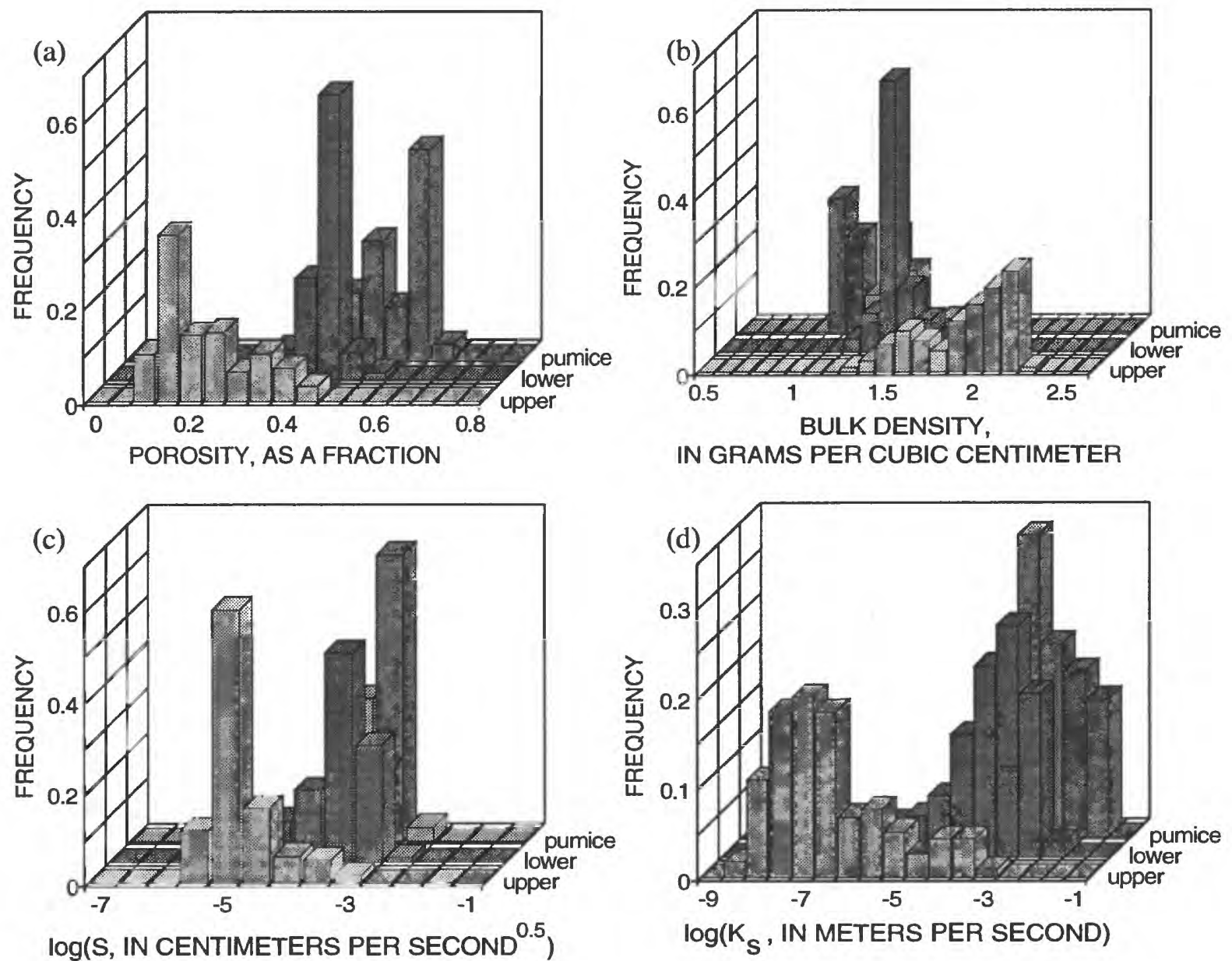

Figure 5. Distribution of values for (a) porosity, (b) bulk density, (c) log sorptivity, and (d) log saturated hydraulic conductivity for the entire shardy-base unit of the Tiva Canyon Tuff of Miocene age, Yucca Mountain, Nevada. "Lower" and "upper" correspond to the lower and upper ash-flow subunits. 
unfragmented glass shards with increased compaction and welding. Because wholly enclosed bubble structures are not accessible by the saturation and waterdisplacement technique underlying Archimedes' principle (see discussion in the "Laboratory Analyses" section), elimination of these intact bubbles indicates that the particle density of the upper ash-flow subunit may be approaching the true grain density of the tuffs.

In terms of flow properties, $\log K_{s}$ diminished markedly with increasing elevation within the shardybase unit. The mean $\log K_{s}$ value in the basal pumicerich air-fall tuff is -2.862 ( $\log$ of meters per second) (table 3 ). The mean value progressively diminished to -3.826 ( $\log$ of meters per second) in the lower ash-flow subunit, and nonlinearly to -6.728 ( $\log$ of meters per second) in the upper ash-flow subunit - a nearly 3-order of magnitude decrease over what is generally a vertical interval of about $5 \mathrm{~m}$. Above the shardy-base interval, saturated hydraulic conductivity values diminished an additional two to four orders of magnitude within the more densely welded, and ubiquitously devitrified, tuffs of the overlying part of the Tiva Canyon Tuff (Flint and others, 1995). Differences in saturated hydraulic conductivity between the locally developed lower Tiva Canyon vitrophyre and the devitrified part of the columnar microstratigraphic unit were not included as part of this investigation. Sorptivity values changed little on average from the basal pumice-rich air-fall tuff to the lower ash-flow subunit; the mean values of sorptivity were -3.452 and $-3.831 \mathrm{log}$ units (table 3 ). However, the more strongly welded upper ash-flow subunit had a mean sorptivity of $-5.082 \log$ units.

These vertical changes in hydrologic properties are shown more precisely as a function of vertical position in figure 6 . Each part of figure 6 is a composite scatterplot (aggregated for all transects) of the selected material property as a function of vertical distance above the base of the basal pumice-rich air-fall tuff. The three-fold subdivision (pumice-rich air-fall tuff, and lower and upper ash-flow tuffs) of the shardy-base unit is quite prominent. The changes in mean property values can be correlated with the gross variations shown on in figure 6. The overall spatial variability of these data was evaluated in greater detail by Rautman and others (1993) and by Istok and others (1994).

The preceding discussion indicates that the hydrologic properties seem to be correlated with one another, except for particle density. These crossvariable correlations are presented graphically in figure 7. The correlation was generally quite strong, as indicated by the coefficient of determination $\left(\mathrm{r}^{2}\right.$ value) shown in each scatterplot. The correlation of the flow properties, saturated hydraulic conductivity, and sorptivity (a surrogate for unsaturated hydraulic conductivity) (log values) with porosity is considered excellent, given that permeability is generally only poorly correlated with porosity. The $r^{2}$ values were 0.824 and 0.825 . Evidently, the genetic physical processes responsible for formation of the lowermost Tiva Canyon Tuff affected the overall pore volume (porosity) and the pore throats (saturated hydraulic conductivity) in a similar manner, which suggests that porosity can be used as a surrogate for the flow properties that are more difficult to measure, at least for rocks of this restricted stratigraphic interval.

\section{SUMMARY}

Laboratory measurement of bulk and fundamental hydrologic properties on samples from an intensive outcrop-sampling program at the base of the Tiva Canyon Tuff of the Paintbrush Group has identified an interval of pronounced change in material character at this stratigraphic level. This interval represents the first major lithologic and material-property change below the present (1994) topographic surface of Yucca Mountain.

The changes in hydrologic properties are systematic and entirely consistent with those expected for the nonwelded to welded transition at the base of a major ash-flow sequence, and they indicate the relatively direct effect of ash-flow consolidation. Porosity decreased with increasing elevation within the unit, indicating progressive compaction and the onset of welding. Conversely, the bulk density of the samples increased with increasing elevation. Saturated hydraulic conductivity and sorptivity (a surrogate for unsaturated conductivity) decreased as the available pore volume, and the size of the pore throats through which water flows, decreased.

The quantitative values of these hydrologic properties may be useful in numerical modeling of groundwater flow and material transport through the upper part of the stratigraphic section at Yucca Mountain. In addition, these quantitative values provide the raw data for improved understanding of the geologic control of spatial variations within ash-flow sheets. 
(a)

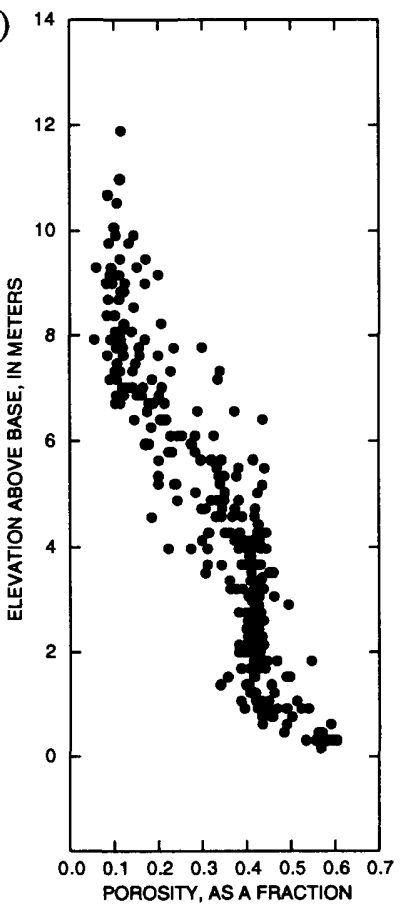

(c)

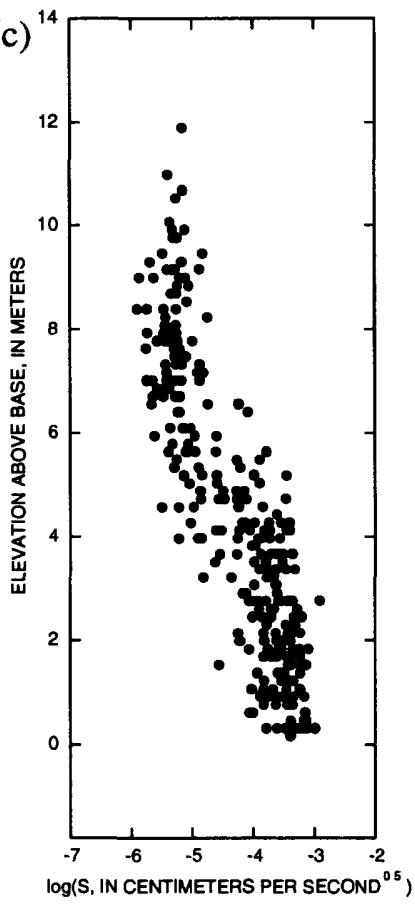

(b)

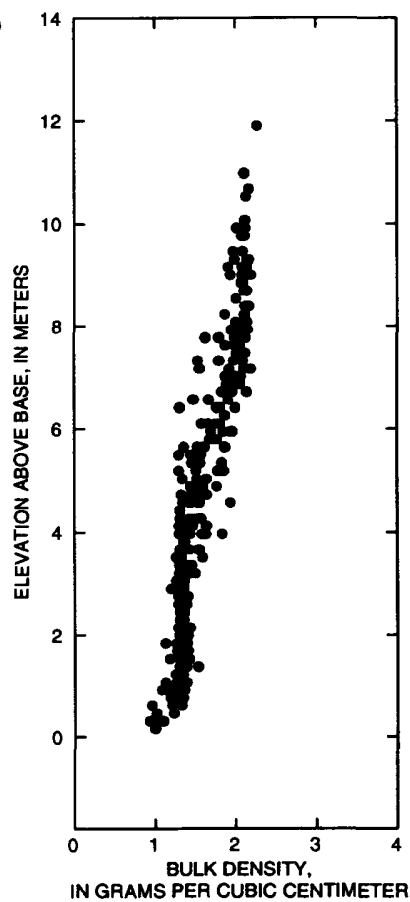

(d)

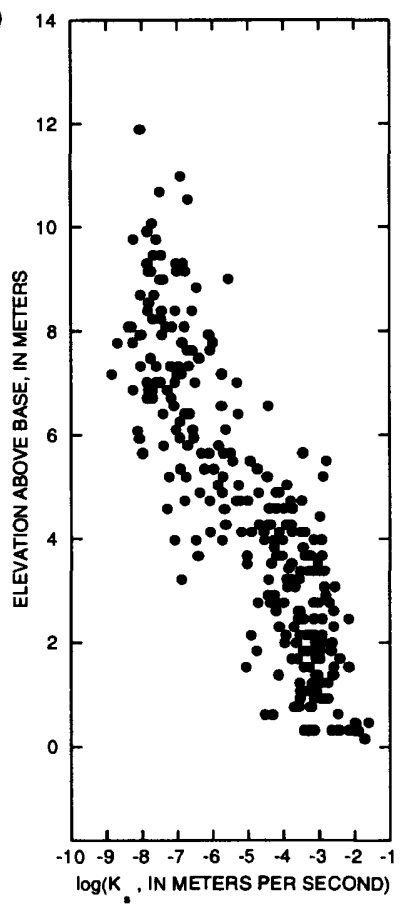

Figure 6. Selected hydrologic properties versus transect elevation, showing vertical control of material properties at Yucca Mountain, Nevada: (a) porosity; (b) bulk density; (c) log sorptivity; (d) log saturated hydraulic conductivity. 

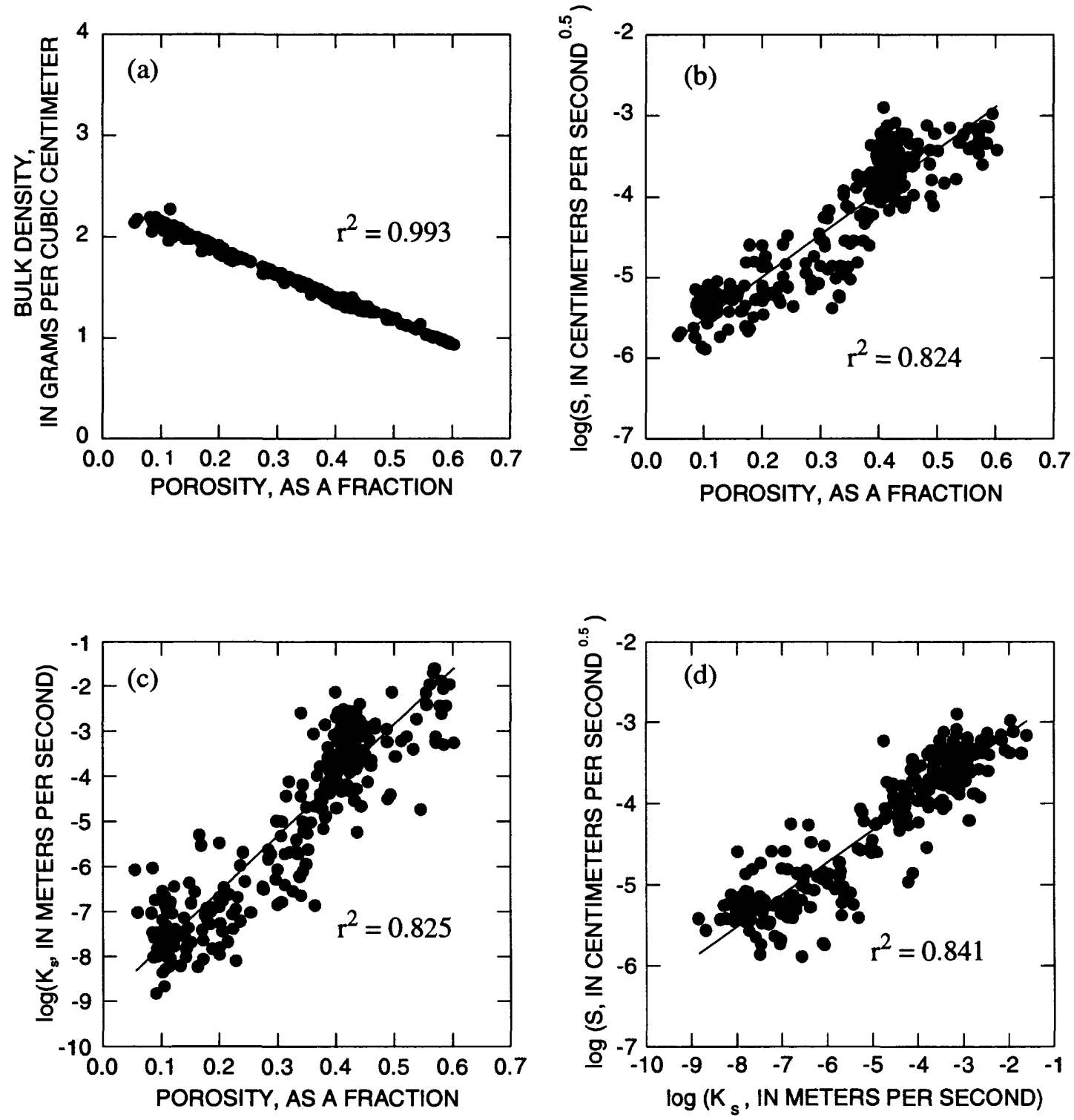

Figure 7. Cross-variable correlations between various hydrologic properties measured on samples from the shardy-base unit at Yucca Mountain, Nevada: (a) bulk density as a function of porosity; (b) log sorptivity as a function of porosity; (c) log saturated hydraulic conductivity as a function of porosity; and (d) log sorptivity as a function of log saturated hydraulic conductivity. 


\section{REFERENCES CITED}

ASTM [American Society for Testing Materials], 1977, Adsorption and bulk-specific gravity of natural building stone: Annual Book of ASTM Standards, part 19, ANSI/ASTM R97-47.

Bush, D.C., and Jenkins, R.E., 1970, Proper hydration of clays for rock property determinations: Journal of Petroleum Technology, v. 22, July, p. 800-804. (NNA.921026.003)

Carr, W.J., 1988, Volcano-tectonic setting of Yucca Mountain and Crater Flat, southwestern Nevada, in Carr, M.D., and Yount, J.C., Geologic and hydrologic investigations of a potential nuclear waste disposal site at Yucca Mountain, southern Nevada: U.S. Geological Survey Bulletin 1790, p. 35-49. (NNA.891114.0346)

Fenix and Scisson, Inc., 1987, NNWSI [Nevada Nuclear Waste Storage Investigations] drilling and mining summary: U.S. Department of Energy, Nevada Operations Office Report DOE/NV/10322-24, 45 p. (NNA.890922.0283)

Flint, A.L., Flint, L.E., and Richards, K.A., 1994, Evaluation of measurement scale using imbibition experiments in volcanic tuffs: Soil Science Society of America Journal, v. 58, p. 94-102.

Flint, L.E., Flint, A.L., Rautman, C.A., and Istok, J.D., 1995, Physical and hydrologic properties of surface outcrop samples at Yucca Mountain, Nevada: U.S. Geological Survey Open-File Report 95-280.

Istok, J.D., Rautman, C.A., Flint, L.E., and Flint, A.L., 1994, Spatial variability of hydrologic properties in a volcanic tuff: Ground Water, v. 32, p. 751-760.

(MOL.19941128.0061)

Nimick, F.B., and Schwartz, B.M., 1987, Bulk, thermal, and mechanical properties of the Topopah Spring Member of the Paintbrush Tuff, Yucca Mountain, Nevada:

Sandia Report SAND85-0762, Sandia National Laboratories, Albuquerque, N. Mex., 180 p. (NNA.871013.0012)

Ortiz, T. S., Williams, R.L., Nimick, F.B., Whittet, B.C., and South, D.L., 1985, A three-dimensional model of reference thermal/mechanical and hydrological stratigraphy at Yucca Mountain, southern Nevada: Sandia Report SAND84-1076, Sandia National Laboratories, Albuquerque, N. Mex., 76 p. (NNA.890315.0013)

Philip, J.R., 1957, Theory of infiltration-1. The infiltration equation and its solution: Soil Science, v. 83 , p. 345-357. (NNA.910820.0012)

Rautman, C.A., and Flint, A.L., 1992, Deterministic geologic processes and stochastic modeling, in High-level radioactive waste management; proceedings of the third international conference: LaGrange Park, Ill., American Nuclear Society, p. 1617-1624. (NNA.920505.0069)

Rautman, C.A., Istok, J.D., Flint, A.L., Flint, L.E., and Chornack, M.P., 1993, Influence of deterministic geologic trends on spatial variability of hydrologic properties in volcanic tuff, in High-level radioactive waste management, proceedings of the fourth international conference: LaGrange Park, Ill., American Nuclear Society, p. 921-929. (NNA.930702.0012)

Sawyer, D.A., Fleck, R.J., Lanphere, M.A., Warren, R.G., Broxton, D.E., and Hudson, M.R., 1994, Episodic caldera volcanism in the Miocene southwest Nevada volcanic field, ${ }^{40} \mathrm{Ar} /{ }^{39} \mathrm{Ar}$ geochronology, and implications for magmatism and extension: Geological Society of America Bulletin, v. 106, no. 10, p. 1304-1318.

Scott, R.B., and Bonk, Jerry., 1984, Preliminary geologic map of Yucca Mountain, Nye County, Nevada, with geologic sections: U.S. Geological Survey Open-File Report 84-494, 10 p. (HQS.880517.1443)

Soeder, D.J., Flint, L.E., and Flint, A.L., 1991, Effects of sample handling and measurement methodology on the determination of porosity in volcanic rock samples [abs.]: Agronomy Abstracts, 1991 Annual Meeting, p. 232. (NNA.920707.0070)

Talsma, T., 1969, In-situ measurement of sorptivity: Australian Journal Soil Research, v. 7, p. 269-276.

(NNA.930330.0088)

NOTE: Parenthesized numbers following each cited reference are for U.S. Department of Energy OCRWM Records Management purposes only and should not be used when ordering the publication. 
18 Physical and Hydrologic Properties of Outcrop Samples from a Nonwelded to Welded Tuff Transition, Yucca Mountaln, Nevada 
APPENDIX 
Table 4. Physical and hydrologic properties of outcrop samples from Yucca Mountain, Nevada, determined by relativehumidity oven drying

[ --, not measured because of sample condition. Exponential notation (E-04 indicating "x $10^{-4}$ ") is used to avoid superscript values in closely spaced tables]

\begin{tabular}{|c|c|c|c|c|c|c|c|c|}
\hline $\begin{array}{c}\text { Sample } \\
\text { Identifi- } \\
\text { cation }\end{array}$ & Subunit & $\begin{array}{c}\text { Height } \\
\text { above } \\
\text { base of } \\
\text { pumice } \\
\text { (meters) }\end{array}$ & $\begin{array}{c}\text { Depth } \\
\text { below } \\
\text { columnar } \\
\text { unit } \\
\text { (meters) }\end{array}$ & $\begin{array}{c}\text { Porosity } \\
\text { (fraction) }\end{array}$ & $\begin{array}{c}\text { Bulk } \\
\text { density } \\
\left(\mathrm{g} / \mathrm{cm}^{3}\right)\end{array}$ & $\begin{array}{l}\text { Particle } \\
\text { density } \\
\left(g / \mathrm{cm}^{3}\right)\end{array}$ & $\begin{array}{l}\text { Sorptivity } \\
(\text { (cm) } \\
(\sqrt{\mathrm{sec}})\end{array}$ & $\begin{array}{l}\text { Saturated } \\
\text { hydraulic } \\
\text { conductivity } \\
\text { (m/sec) }\end{array}$ \\
\hline \multicolumn{9}{|c|}{ Transect SB-1 } \\
\hline SB1-1 & pumice & 0.30 & -8.23 & 0.573 & 1.00 & 2.33 & 3.37E-04 & $5.44 \mathrm{E}-04$ \\
\hline SB1-2 & pumice & 0.91 & -7.62 & 0.491 & 1.20 & 2.36 & $1.61 \mathrm{E}-04$ & -- \\
\hline SB1-3 & lower & 1.07 & -7.47 & 0.513 & 1.13 & 2.32 & $1.47 \mathrm{E}-04$ & $5.75 \mathrm{E}-04$ \\
\hline SB 1-4 & lower & 1.68 & -6.86 & 0.427 & 1.33 & 2.32 & 2.43E-04 & -- \\
\hline SB1-5 & lower & 2.44 & -6.10 & 0.409 & 1.37 & 2.33 & -- & -- \\
\hline SB 1-6 & lower & 2.74 & -5.79 & 0.405 & 1.38 & 2.32 & $2.62 \mathrm{E}-04$ & $7.59 \mathrm{E}-04$ \\
\hline SB $1-7$ & upper & 3.96 & -4.57 & 0.382 & 1.44 & 2.33 & $5.54 \mathrm{E}-05$ & $5.22 \mathrm{E}-05$ \\
\hline SB $1-8$ & upper & 4.88 & -3.66 & 0.320 & 1.60 & 2.35 & $1.38 \mathrm{E}-05$ & 7.54E-05 \\
\hline SB1-9 & upper & 7.01 & -1.52 & 0.166 & 1.98 & 2.37 & $3.80 \mathrm{E}-06$ & $4.91 \mathrm{E}-06$ \\
\hline SB1-10 & upper & 7.92 & -0.61 & 0.056 & 2.14 & 2.27 & $1.87 \mathrm{E}-06$ & 8.09E-07 \\
\hline \multicolumn{9}{|c|}{ Transect SB-2 } \\
\hline SB2-1 & pumice & 0.46 & -8.61 & 0.562 & 1.02 & 2.32 & 4.14E-04 & $1.07 \mathrm{E}-02$ \\
\hline SB2-2 & lower & 0.76 & -8.31 & 0.455 & 1.31 & 2.40 & $4.43 \mathrm{E}-04$ & $2.05 \mathrm{E}-04$ \\
\hline SB2-3 & lower & 1.83 & -7.24 & 0.428 & 1.32 & 2.32 & $2.63 \mathrm{E}-04$ & $2.24 \mathrm{E}-03$ \\
\hline SB2-4 & lower & 2.44 & -6.63 & 0.422 & 1.33 & 2.30 & 4.73E-04 & $3.69 \mathrm{E}-04$ \\
\hline SB2-5 & lower & 3.05 & -6.02 & 0.429 & 1.32 & 2.31 & -- & $-\cdot$ \\
\hline SB2-6 & lower & 4.11 & -4.95 & 0.377 & 1.45 & 2.33 & $1.72 \mathrm{E}-04$ & 2.85E-05 \\
\hline SB2-7 & upper & 4.72 & -4.34 & 0.306 & 1.62 & 2.33 & $2.76 \mathrm{E}-05$ & 4.70E-06 \\
\hline SB2-8 & upper & 5.94 & -3.12 & 0.276 & 1.70 & 2.34 & $1.12 \mathrm{E}-05$ & $3.06 \mathrm{E}-07$ \\
\hline SB2-9 & upper & 6.86 & -2.21 & 0.163 & 1.99 & 2.37 & $3.78 \mathrm{E}-06$ & $5.71 \mathrm{E}-09$ \\
\hline SB2-10 & upper & 7.77 & -1.30 & 0.112 & 2.12 & 2.38 & $4.46 \mathrm{E}-06$ & - \\
\hline SB2-11 & upper & 8.38 & -0.69 & 0.084 & 2.17 & 2.37 & $1.84 \mathrm{E}-06$ & $9.04 \mathrm{E}-08$ \\
\hline \multicolumn{9}{|c|}{ Transect SB-3 } \\
\hline SB3-1 & pumice & 0.46 & -8.99 & 0.570 & 1.01 & 2.34 & $6.76 \mathrm{E}-04$ & $2.47 \mathrm{E}-02$ \\
\hline SB3-2 & pumice & 1.07 & -8.38 & 0.434 & 1.34 & 2.37 & $3.51 \mathrm{E}-04$ & $7.57 \mathrm{E}-04$ \\
\hline SB3-3 & lower & 1.68 & -7.77 & 0.442 & 1.27 & 2.27 & 5.92E-04 & 3.87E-03 \\
\hline SB3-4 & lower & 2.13 & -7.31 & 0.409 & 1.34 & 2.27 & $4.36 \mathrm{E}-04$ & $2.92 \mathrm{E}-04$ \\
\hline SB3-5 & lower & 2.96 & -6.49 & 0.412 & 1.35 & 2.29 & -- & -- \\
\hline SB3-6 & lower & 3.51 & -5.94 & 0.451 & 1.27 & 2.32 & $3.00 \mathrm{E}-04$ & $9.24 \mathrm{E}-04$ \\
\hline SB3-7 & upper ${ }^{\circ}$ & 4.27 & -5.18 & 0.364 & 1.47 & 2.31 & $1.80 \mathrm{E}-04$ & $2.09 \mathrm{E}-05$ \\
\hline SB3-8 & upper & 4.72 & -4.72 & 0.299 & 1.62 & 2.31 & $3.43 \mathrm{E}-05$ & $9.92 \mathrm{E}-06$ \\
\hline SB3-9 & upper & 6.10 & -3.35 & 0.244 & 1.78 & 2.35 & $7.55 \mathrm{E}-06$ & -- \\
\hline SB3-10 & upper & 7.77 & -1.68 & 0.121 & 2.08 & 2.36 & 3.63E-06 & -- \\
\hline SB3-11 & upper & 8.99 & -0.46 & 0.124 & 2.08 & 2.37 & $6.27 \mathrm{E}-06$ & $4.13 \mathrm{E}-08$ \\
\hline \multicolumn{9}{|c|}{ Transect SB-4 } \\
\hline SB4-1 & pumice & 0.30 & -9.14 & 0.572 & 1.01 & 2.35 & $4.96 \mathrm{E}-04$ & $7.41 \mathrm{E}-04$ \\
\hline SB4-2 & pumice & 0.76 & -8.69 & 0.459 & 1.28 & 2.36 & $2.34 \mathrm{E}-04$ & $6.20 \mathrm{E}-04$ \\
\hline SB4-3 & lower & 1.22 & -8.23 & 0.462 & 1.25 & 2.33 & $3.08 \mathrm{E}-04$ & $1.24 \mathrm{E}-03$ \\
\hline SB4-4 & lower & 1.83 & -7.62 & 0.432 & 1.31 & 2.31 & $2.96 \mathrm{E}-04$ & $4.66 \mathrm{E}-04$ \\
\hline SB4-5 & lower & 2.59 & -6.86 & 0.403 & 1.39 & 2.33 & -- & -- \\
\hline
\end{tabular}


Table 4. Physical and hydrologic properties of outcrop samples from Yucca Mountain, Nevada, determined by relativehumidity oven drying--Continued

\begin{tabular}{|c|c|c|c|c|c|c|c|c|}
\hline $\begin{array}{l}\text { Sample } \\
\text { Identifi- } \\
\text { cation }\end{array}$ & Subunit & $\begin{array}{l}\text { Height } \\
\text { above } \\
\text { base of } \\
\text { pumice } \\
\text { (meters) }\end{array}$ & $\begin{array}{c}\text { Depth } \\
\text { below } \\
\text { columnar } \\
\text { unit } \\
\text { (meters) }\end{array}$ & $\begin{array}{l}\text { Porosity } \\
\text { (fraction) }\end{array}$ & $\begin{array}{c}\text { Bulk } \\
\text { density } \\
\left(\mathrm{g} / \mathrm{cm}^{3}\right)\end{array}$ & $\begin{array}{l}\text { Particle } \\
\text { density } \\
\left(\mathrm{g} / \mathrm{cm}^{3}\right)\end{array}$ & $\begin{array}{l}\text { Sorptivity } \\
\text { (cm/ } \\
(\sqrt{\mathrm{sec}})\end{array}$ & $\begin{array}{c}\text { Saturated } \\
\text { hydraulic } \\
\text { conductivity } \\
\text { (m/sec) }\end{array}$ \\
\hline \multicolumn{9}{|c|}{ Transect SB-4--Continued } \\
\hline SB4-6 & lower & 3.66 & -5.79 & 0.432 & 1.32 & 2.32 & $2.41 \mathrm{E}-04$ & $4.00 \mathrm{E}-04$ \\
\hline SB4-7 & lower & 4.11 & -5.33 & 0.428 & 1.33 & 2.33 & 8.85E-05 & $1.71 \mathrm{E}-04$ \\
\hline SB4-8 & upper & 5.03 & -4.42 & 0.351 & 1.52 & 2.34 & $2.58 \mathrm{E}-05$ & 5.39E-06 \\
\hline SB4-9 & upper & 7.62 & -1.83 & 0.085 & 2.05 & 2.24 & $1.76 \mathrm{E}-06$ & 8.79E-07 \\
\hline SB4-10 & upper & 8.38 & -1.07 & 0.103 & 2.12 & 2.37 & $1.27 \mathrm{E}-06$ & 2.77E-07 \\
\hline SB4-11 & upper & 9.14 & -0.30 & 0.090 & 2.14 & 2.35 & $3.86 \mathrm{E}-06$ & $1.76 \mathrm{E}-07$ \\
\hline \multicolumn{9}{|c|}{ Transect SB-5 } \\
\hline SB5-1 & pumice & 0.61 & -8.76 & 0.589 & 0.96 & 2.35 & 7.14E-04 & $3.49 \mathrm{E}-03$ \\
\hline SB5-2 & pumice & 0.91 & -8.46 & 0.539 & 1.08 & 2.35 & $4.59 \mathrm{E}-04$ & $1.78 \mathrm{E}-03$ \\
\hline SB5-3 & lower & 1.83 & -7.54 & 0.447 & 1.27 & 2.30 & 8.57E-05 & $3.60 \mathrm{E}-04$ \\
\hline SB5-4 & lower & 2.13 & -7.24 & 0.438 & 1.29 & 2.30 & $5.83 \mathrm{E}-04$ & $1.25 \mathrm{E}-03$ \\
\hline SB5-5 & lower & 2.90 & -6.48 & 0.419 & 1.36 & 2.33 & $6.83 \mathrm{E}-05$ & $5.61 \mathrm{E}-05$ \\
\hline SB5-6 & lower & 3.35 & -6.02 & 0.409 & 1.37 & 2.32 & $3.46 \mathrm{E}-04$ & $3.06 \mathrm{E}-04$ \\
\hline SB5-7 & upper & 4.27 & -5.11 & 0.427 & 1.34 & 2.33 & $3.97 \mathrm{E}-04$ & $1.65 \mathrm{E}-04$ \\
\hline SB5-8 & upper & 4.72 & -4.65 & 0.374 & 1.46 & 2.34 & 2.79E-05 & $1.61 \mathrm{E}-04$ \\
\hline SB5-9 & upper & 5.64 & -3.73 & 0.344 & 1.53 & 2.33 & $1.14 \mathrm{E}-05$ & $7.81 \mathrm{E}-07$ \\
\hline SB5-10 & upper & 6.55 & -2.82 & 0.289 & 1.67 & 2.34 & $1.83 \mathrm{E}-05$ & $1.85 \mathrm{E}-06$ \\
\hline SB5-11 & upper & 7.92 & -1.45 & 0.171 & 1.95 & 2.35 & $4.47 \mathrm{E}-06$ & $3.78 \mathrm{E}-08$ \\
\hline SB5-12 & upper & 8.53 & -0.84 & 0.144 & 2.01 & 2.35 & $8.30 \mathrm{E}-06$ & $1.61 \mathrm{E}-08$ \\
\hline SB5-13 & upper & 9.30 & -0.08 & 0.094 & 2.14 & 2.36 & $6.61 \mathrm{E}-06$ & $1.47 \mathrm{E}-08$ \\
\hline \multicolumn{9}{|c|}{ Transect SB-6 } \\
\hline SB6-1 & pumice & 0.91 & -8.23 & 0.522 & 1.12 & 2.34 & $6.91 \mathrm{E}-04$ & 7.32E-04 \\
\hline SB6-2 & pumice & 1.37 & -7.77 & 0.456 & 1.30 & 2.38 & $2.56 \mathrm{E}-04$ & 7.34E-05 \\
\hline SB6-3 & lower & 1.98 & -7.16 & 0.402 & 1.39 & 2.32 & $1.54 \mathrm{E}-04$ & $1.11 \mathrm{E}-04$ \\
\hline SB6-4 & lower & 2.74 & -6.40 & 0.400 & 1.40 & 2.33 & $1.06 \mathrm{E}-04$ & $1.02 \mathrm{E}-04$ \\
\hline SB6-5 & lower & 3.41 & -5.73 & 0.435 & 1.32 & 2.33 & $1.60 \mathrm{E}-04$ & $1.42 \mathrm{E}-04$ \\
\hline SB6-6 & lower & 3.96 & -5.18 & 0.433 & 1.32 & 2.32 & $1.21 \mathrm{E}-04$ & 2.84E-05 \\
\hline SB6-7 & upper & 5.33 & -3.81 & 0.349 & 1.52 & 2.34 & $1.34 \mathrm{E}-05$ & $1.10 \mathrm{E}-06$ \\
\hline SB6-8 & upper & 5.79 & -3.35 & 0.285 & 1.68 & 2.35 & 8.62E-06 & $1.50 \mathrm{E}-06$ \\
\hline SB6-9 & upper & 6.71 & -2.44 & 0.179 & 1.93 & 2.35 & $2.30 \mathrm{E}-06$ & $6.82 \mathrm{E}-08$ \\
\hline SB6-10 & upper & 7.47 & -1.68 & 0.149 & 2.02 & 2.38 & $5.23 \mathrm{E}-06$ & $4.26 \mathrm{E}-07$ \\
\hline SB6-11 & upper & 8.23 & -0.91 & 0.122 & 2.11 & 2.41 & 3.67E-06 & $2.12 \mathrm{E}-08$ \\
\hline SB6-12 & upper & 8.99 & -0.15 & 0.082 & 2.19 & 2.39 & 2.35E-06 & -- \\
\hline \multicolumn{9}{|c|}{ Transect SB-7 } \\
\hline SB7-1 & pumice & 0.30 & -7.85 & 0.572 & 1.00 & 2.34 & $5.75 \mathrm{E}-04$ & $5.98 \mathrm{E}-04$ \\
\hline SB7-2 & pumice & 0.76 & -7.39 & 0.503 & 1.19 & 2.39 & $3.63 \mathrm{E}-04$ & $2.69 \mathrm{E}-04$ \\
\hline SB7-3 & lower & 1.22 & -6.93 & 0.417 & 1.31 & 2.25 & $1.52 \mathrm{E}-04$ & -- \\
\hline SB7-4 & lower & 1.68 & -6.48 & 0.388 & 1.39 & 2.28 & $1.96 \mathrm{E}-04$ & $1.76 \mathrm{E}-04$ \\
\hline SB7-5 & lower & 2.29 & -5.87 & 0.403 & 1.36 & 2.28 & $3.41 \mathrm{E}-04$ & $7.74 \mathrm{E}-05$ \\
\hline SB7-6 & lower & 2.74 & -5.41 & 0.383 & 1.41 & 2.28 & $1.63 \mathrm{E}-04$ & 4.59E-05 \\
\hline
\end{tabular}


Table 4. Physical and hydrologic properties of outcrop samples from Yucca Mountain, Nevada, determined by relativehumidity oven drying--Continued

\begin{tabular}{|c|c|c|c|c|c|c|c|c|}
\hline $\begin{array}{c}\text { Sample } \\
\text { Identifi- } \\
\text { cation }\end{array}$ & Subunit & $\begin{array}{l}\text { Height } \\
\text { above } \\
\text { base of } \\
\text { pumice } \\
\text { (meters) }\end{array}$ & $\begin{array}{c}\text { Depth } \\
\text { below } \\
\text { columnar } \\
\text { unit } \\
\text { (meters) }\end{array}$ & $\begin{array}{l}\text { Porosity } \\
\text { (fraction) }\end{array}$ & $\begin{array}{c}\text { Bulk } \\
\text { density } \\
\left(\mathrm{g} / \mathrm{cm}^{3}\right)\end{array}$ & $\begin{array}{l}\text { Particle } \\
\text { density } \\
\left(\mathrm{g} / \mathrm{cm}^{3}\right)\end{array}$ & $\begin{array}{c}\text { Sorptivity } \\
\text { (cm/ } \\
(\sqrt{\mathrm{sec}})\end{array}$ & $\begin{array}{c}\text { Saturated } \\
\text { hydraulic } \\
\text { conductivity } \\
\text { (m/sec) }\end{array}$ \\
\hline \multicolumn{9}{|c|}{ Transect SB-7--Continued } \\
\hline SB7-7 & lower & 3.96 & -4.19 & 0.275 & 1.63 & 2.24 & $1.49 \mathrm{E}-05$ & $3.48 \mathrm{E}-07$ \\
\hline SB7-8 & upper & 5.18 & -2.97 & 0.200 & 1.86 & 2.32 & 7.19E-06 & 1.83E-07 \\
\hline SB7-9 & upper & 7.01 & -1.14 & 0.143 & 2.02 & 2.35 & $6.56 \mathrm{E}-06$ & $1.44 \mathrm{E}-08$ \\
\hline SB7-10 & upper & 7.77 & -0.38 & 0.106 & 2.13 & 2.38 & $2.70 \mathrm{E}-06$ & $2.06 \mathrm{E}-09$ \\
\hline \multicolumn{9}{|c|}{ Transect SB-8 } \\
\hline SB8-1 & pumice & 0.30 & -7.31 & 0.586 & 0.97 & 2.35 & 4.53E-04 & 4.93E-04 \\
\hline SB8-2 & pumice & 0.46 & -7.16 & 0.484 & 1.23 & 2.39 & $7.45 \mathrm{E}-04$ & -- \\
\hline SB8-3 & lower & 1.22 & -6.40 & 0.414 & 1.35 & 2.31 & 4.57E-04 & $2.88 \mathrm{E}-04$ \\
\hline SB8-4 & lower & 1.68 & -5.94 & 0.406 & 1.38 & 2.32 & $1.49 \mathrm{E}-04$ & 8.29E-04 \\
\hline SB8-5 & lower & 2.13 & -5.49 & 0.382 & 1.44 & 2.33 & $5.53 \mathrm{E}-05$ & $1.26 \mathrm{E}-05$ \\
\hline SB8-6 & lower & 2.74 & -4.88 & 0.402 & 1.40 & 2.34 & $8.58 \mathrm{E}-05$ & $1.94 \mathrm{E}-05$ \\
\hline SB8-7 & lower & 3.20 & -4.42 & 0.364 & 1.50 & 2.35 & $1.53 \mathrm{E}-05$ & $1.35 \mathrm{E}-07$ \\
\hline SB8-8 & upper & 3.96 & -3.66 & 0.223 & 1.83 & 2.35 & $5.96 \mathrm{E}-06$ & 8.52E-08 \\
\hline SB8-9 & upper & 4.57 & -3.05 & 0.185 & 1.94 & 2.39 & $3.19 \mathrm{E}-06$ & 5.15E-08 \\
\hline SB8-10 & upper & 6.71 & -0.91 & 0.104 & 2.14 & 2.39 & $3.40 \mathrm{E}-06$ & $1.81 \mathrm{E}-08$ \\
\hline SB8-11 & upper & 7.16 & -0.46 & 0.092 & 2.19 & 2.41 & $3.79 \mathrm{E}-06$ & $1.45 \mathrm{E}-09$ \\
\hline \multicolumn{9}{|c|}{ Transect SB-9 } \\
\hline SB9-1 & pumice & 0.30 & -8.76 & 0.533 & 1.10 & 2.35 & $1.63 \mathrm{E}-04$ & $3.87 \mathrm{E}-04$ \\
\hline SB9-2 & lower & 1.22 & -7.85 & 0.407 & 1.35 & 2.28 & $3.91 \mathrm{E}-04$ & $1.84 \mathrm{E}-03$ \\
\hline SB9-3 & lower & 1.68 & -7.39 & 0.387 & 1.41 & 2.30 & 4.27E-04 & $2.50 \mathrm{E}-04$ \\
\hline SB9-4 & lower & 2.59 & -6.48 & 0.419 & 1.36 & 2.35 & $1.27 \mathrm{E}-04$ & $6.39 \mathrm{E}-05$ \\
\hline SB9-5 & lower & 2.90 & -6.17 & 0.494 & 1.20 & 2.36 & $7.74 \mathrm{E}-05$ & $3.78 \mathrm{E}-05$ \\
\hline SB9-6 & lower & 3.66 & -5.41 & 0.343 & 1.55 & 2.37 & 2.83E-05 & $9.55 \mathrm{E}-06$ \\
\hline SB9-7 & upper & 4.72 & -4.34 & 0.307 & 1.64 & 2.37 & $5.44 \mathrm{E}-05$ & $1.60 \mathrm{E}-07$ \\
\hline SB9-8 & upper & 5.18 & -3.89 & 0.236 & 1.80 & 2.36 & $2.55 \mathrm{E}-05$ & $5.98 \mathrm{E}-08$ \\
\hline SB9-9 & upper & 5.94 & -3.12 & 0.179 & 1.96 & 2.39 & $2.51 \mathrm{E}-05$ & $1.18 \mathrm{E}-07$ \\
\hline SB9-9f & upper & 5.94 & -3.12 & 0.172 & 1.94 & 2.34 & -- & 8.49E-09 \\
\hline SB9-10 & upper & 7.01 & -2.06 & 0.141 & 2.05 & 2.39 & $2.24 \mathrm{E}-06$ & $2.65 \mathrm{E}-08$ \\
\hline SB9-11 & upper & 8.08 & -0.99 & 0.108 & 2.14 & 2.40 & $5.44 \mathrm{E}-06$ & 4.80E-08 \\
\hline SB9-12 & columnar & 8.84 & -0.23 & 0.123 & 2.15 & 2.45 & $6.57 \mathrm{E}-06$ & 2.99E-07 \\
\hline \multicolumn{9}{|c|}{ Transect SB-10 } \\
\hline SB10-1 & & -0.30 & -8.76 & 0.435 & 1.27 & 2.25 & $1.03 \mathrm{E}-04$ & $5.65 \mathrm{E}-05$ \\
\hline SB10-2 & lower & 1.07 & -7.39 & 0.450 & 1.26 & 2.29 & $5.80 \mathrm{E}-04$ & $3.10 \mathrm{E}-04$ \\
\hline SB10-3 & lower & 1.83 & -6.63 & 0.429 & 1.40 & 2.46 & $8.03 \mathrm{E}-04$ & $7.35 \mathrm{E}-04$ \\
\hline SB10-4 & lower & 2.29 & -6.17 & 0.416 & 1.34 & 2.29 & $1.68 \mathrm{E}-04$ & $1.96 \mathrm{E}-04$ \\
\hline SB10-5 & lower & 2.74 & -5.71 & 0.427 & 1.31 & 2.29 & $1.12 \mathrm{E}-04$ & $4.41 \mathrm{E}-05$ \\
\hline SB10-6 & lower & 3.66 & -4.80 & 0.313 & 1.54 & 2.24 & $5.38 \mathrm{E}-05$ & $3.88 \mathrm{E}-07$ \\
\hline SB10-7 & lower & 4.11 & -4.34 & 0.300 & 1.64 & 2.34 & $2.98 \mathrm{E}-05$ & 8.58E-07 \\
\hline SB10-8 & lower & 4.88 & -3.58 & 0.244 & 1.77 & 2.34 & 3.27E-05 & 4.45E-07 \\
\hline SB10-9 & upper & 5.64 & -2.82 & 0.200 & 1.87 & 2.34 & $2.47 \mathrm{E}-05$ & $1.06 \mathrm{E}-08$ \\
\hline
\end{tabular}


Table 4. Physical and hydrologic properties of outcrop samples from Yucca Mountain, Nevada, determined by relativehumidity oven drying--Continued

\begin{tabular}{|c|c|c|c|c|c|c|c|c|}
\hline $\begin{array}{c}\text { Sample } \\
\text { Identifi- } \\
\text { cation }\end{array}$ & Subunit & $\begin{array}{l}\text { Height } \\
\text { above } \\
\text { base of } \\
\text { pumice } \\
\text { (meters) }\end{array}$ & $\begin{array}{c}\text { Depth } \\
\text { below } \\
\text { columnar } \\
\text { unit } \\
\text { (meters) }\end{array}$ & $\begin{array}{l}\text { Porosity } \\
\text { (fraction) }\end{array}$ & $\begin{array}{c}\text { Bulk } \\
\text { density } \\
\left(\mathrm{g} / \mathrm{cm}^{3}\right)\end{array}$ & $\begin{array}{l}\text { Particle } \\
\text { density } \\
\left(\mathrm{g} / \mathrm{cm}^{3}\right)\end{array}$ & $\begin{array}{l}\text { Sorptivity } \\
(\mathbf{c m} / \\
(\sqrt{\sec })\end{array}$ & $\begin{array}{c}\text { Saturated } \\
\text { hydraulic } \\
\text { conductivity } \\
\text { (m/sec) }\end{array}$ \\
\hline \multicolumn{9}{|c|}{ Transect SB-10--Continued } \\
\hline SB10-10 & upper & 6.40 & -2.06 & 0.147 & 2.00 & 2.34 & -- & 4.17E-08 \\
\hline SB10-11 & upper & 7.01 & -1.45 & 0.120 & 2.07 & 2.35 & $5.19 \mathrm{E}-06$ & 8.73E-08 \\
\hline SB10-12 & upper & 7.31 & -1.14 & 0.110 & 2.08 & 2.34 & $6.78 \mathrm{E}-06$ & $9.42 \mathrm{E}-09$ \\
\hline SB10-13 & upper & 7.92 & -0.53 & 0.094 & 2.15 & 2.37 & 5.57E-06 & $9.90 \mathrm{E}-09$ \\
\hline \multicolumn{9}{|c|}{ Transect SB-11 } \\
\hline SB11-1 & lower & 1.52 & -10.74 & 0.358 & 1.43 & 2.23 & $2.82 \mathrm{E}-05$ & $9.19 \mathrm{E}-06$ \\
\hline SB11-2 & lower & 1.83 & -10.44 & 0.546 & 1.13 & 2.49 & $5.69 \mathrm{E}-04$ & $1.77 \mathrm{E}-05$ \\
\hline SB11-3 & lower & 2.44 & -9.83 & 0.410 & 1.33 & 2.25 & $6.29 \mathrm{E}-04$ & $1.24 \mathrm{E}-03$ \\
\hline SB 11-4 & lower & 3.05 & -9.22 & 0.413 & 1.33 & 2.28 & $2.34 \mathrm{E}-04$ & $1.43 E-03$ \\
\hline SB11-5 & lower & 3.51 & -8.76 & 0.411 & 1.33 & 2.26 & $1.62 \mathrm{E}-04$ & $4.56 \mathrm{E}-05$ \\
\hline SB11-6 & lower & 3.96 & -8.31 & 0.400 & 1.36 & 2.26 & $2.71 \mathrm{E}-04$ & $9.30 \mathrm{E}-05$ \\
\hline SB11-7 & lower & 4.72 & -7.54 & 0.420 & 1.32 & 2.27 & $3.46 \mathrm{E}-04$ & 3.33E-04 \\
\hline SB11-8 & lower & 5.49 & -6.78 & 0.441 & 1.30 & 2.33 & $1.32 \mathrm{E}-04$ & $1.66 \mathrm{E}-03$ \\
\hline SB11-9 & lower & 6.40 & -5.87 & 0.437 & 1.31 & 2.32 & $8.42 \mathrm{E}-05$ & $5.50 \mathrm{E}-06$ \\
\hline SB11-10 & lower & 7.31 & -4.95 & 0.341 & 1.54 & 2.34 & $1.35 \mathrm{E}-05$ & $2.20 \mathrm{E}-07$ \\
\hline SB11-11 & upper & 7.77 & -4.50 & 0.300 & 1.63 & 2.33 & - & $1.41 \mathrm{E}-07$ \\
\hline SB11-12 & upper & 8.23 & -4.04 & 0.206 & 1.87 & 2.36 & $1.80 \mathrm{E}-05$ & $3.50 \mathrm{E}-08$ \\
\hline SB11-13 & upper & 9.14 & -3.12 & 0.201 & 1.91 & 2.39 & $1.34 \mathrm{E}-05$ & $1.56 \mathrm{E}-08$ \\
\hline SB11-14 & upper & 9.91 & -2.36 & 0.145 & 2.02 & 2.37 & $7.61 \mathrm{E}-06$ & $1.47 \mathrm{E}-08$ \\
\hline SB11-15 & upper & 10.97 & -1.30 & 0.114 & 2.11 & 2.38 & $4.04 \mathrm{E}-06$ & $1.29 \mathrm{E}-07$ \\
\hline SB11-16 & upper & 11.89 & -0.38 & 0.117 & 2.27 & 2.57 & $6.91 \mathrm{E}-06$ & $8.90 \mathrm{E}-09$ \\
\hline \multicolumn{9}{|c|}{ Transect SB-12 } \\
\hline SB12-1 & pumice & 1.52 & -6.40 & 0.497 & 1.18 & 2.35 & $5.90 \mathrm{E}-04$ & $7.06 \mathrm{E}-03$ \\
\hline SB12-2 & pumice & 1.83 & -6.10 & 0.468 & 1.26 & 2.37 & $4.50 \mathrm{E}-04$ & $1.11 \mathrm{E}-03$ \\
\hline SB12-3 & lower & 2.74 & -5.18 & 0.409 & 1.36 & 2.30 & $1.24 \mathrm{E}-03$ & $7.14 \mathrm{E}-04$ \\
\hline SB12-4 & lower & 3.35 & -4.57 & 0.362 & 1.46 & 2.29 & $1.26 \mathrm{E}-04$ & $8.45 \mathrm{E}-04$ \\
\hline SB12-5 & lower & 4.11 & -3.81 & 0.431 & 1.30 & 2.28 & $3.56 \mathrm{E}-04$ & $4.01 \mathrm{E}-04$ \\
\hline SB12-6 & lower & 5.03 & -2.90 & 0.426 & 1.34 & 2.33 & $1.29 \mathrm{E}-04$ & $1.27 \mathrm{E}-04$ \\
\hline SB12-7 & lower & 5.49 & -2.44 & 0.382 & 1.45 & 2.35 & $5.37 \mathrm{E}-05$ & $1.17 \mathrm{E}-05$ \\
\hline SB12-8 & upper & 6.10 & -1.83 & 0.229 & 1.81 & 2.35 & $7.48 \mathrm{E}-06$ & 7.62E-09 \\
\hline SB 12-9 & upper & 6.71 & -1.22 & 0.189 & 1.92 & 2.36 & $5.27 \mathrm{E}-06$ & $1.44 \mathrm{E}-08$ \\
\hline SB12-10 & upper & 7.16 & -0.76 & 0.107 & 2.11 & 2.37 & $3.91 \mathrm{E}-06$ & $1.34 \mathrm{E}-07$ \\
\hline SB12-11 & upper & 7.47 & -0.46 & 0.108 & 2.12 & 2.38 & 8.03E-06 & $1.84 \mathrm{E}-08$ \\
\hline \multicolumn{9}{|c|}{ Transect SB-13 } \\
\hline SB 13-1 & pumice & 0.15 & -8.23 & 0.568 & 1.00 & 2.31 & 4.07E-04 & $1.94 \mathrm{E}-02$ \\
\hline SB13-2 & pumice & 0.76 & -7.62 & 0.434 & 1.35 & 2.38 & $1.49 \mathrm{E}-04$ & $5.64 \mathrm{E}-04$ \\
\hline SB13-3 & lower & 1.07 & -7.31 & 0.387 & 1.39 & 2.26 & $9.41 \mathrm{E}-05$ & 4.27E-04 \\
\hline SB 13-4 & lower & 1.37 & -7.01 & 0.406 & 1.35 & 2.27 & 3.23E-04 & $9.31 \mathrm{E}-04$ \\
\hline SB13-5 & lower & 2.44 & -5.94 & 0.410 & 1.36 & 2.30 & $9.79 \mathrm{E}-05$ & $2.92 \mathrm{E}-04$ \\
\hline SB13-6 & lower & 3.20 & -5.18 & 0.377 & 1.44 & 2.30 & 4.57E-05 & $3.96 \mathrm{E}-05$ \\
\hline
\end{tabular}


Table 4. Physical and hydrologic properties of outcrop samples from Yucca Mountain, Nevada, determined by relativehumidity oven drying--Continued

\begin{tabular}{|c|c|c|c|c|c|c|c|c|}
\hline $\begin{array}{l}\text { Sample } \\
\text { Identifi- } \\
\text { cation }\end{array}$ & Subunit & $\begin{array}{l}\text { Height } \\
\text { above } \\
\text { base of } \\
\text { pumice } \\
\text { (meters) }\end{array}$ & $\begin{array}{c}\text { Depth } \\
\text { below } \\
\text { columnar } \\
\text { unit } \\
\text { (meters) }\end{array}$ & $\begin{array}{l}\text { Porosity } \\
\text { (fraction) }\end{array}$ & $\begin{array}{c}\text { Bulk } \\
\text { density } \\
\left(\mathrm{g} / \mathrm{cm}^{3}\right)\end{array}$ & $\begin{array}{l}\text { Particle } \\
\text { density } \\
\left(\mathrm{g} / \mathrm{cm}^{3}\right)\end{array}$ & $\begin{array}{c}\text { Sorptivity } \\
\text { (cm) } \\
(\sqrt{\sec })\end{array}$ & $\begin{array}{c}\text { Saturated } \\
\text { hydraullc } \\
\text { conductivity } \\
\text { (m/sec) }\end{array}$ \\
\hline \multicolumn{9}{|c|}{ Transect SB-13--Continued } \\
\hline SB13-7 & lower & 3.96 & -4.42 & 0.312 & 1.58 & 2.30 & $1.25 \mathrm{E}-05$ & $1.86 \mathrm{E}-06$ \\
\hline SB13-8 & lower & 4.72 & -3.66 & 0.300 & 1.64 & 2.34 & $1.39 \mathrm{E}-05$ & 8.37E-07 \\
\hline SB13-9 & upper & 5.33 & -3.05 & 0.201 & 1.83 & 2.29 & $5.10 \mathrm{E}-06$ & $1.21 \mathrm{E}-07$ \\
\hline SB13-10 & upper & 6.86 & -1.52 & 0.106 & 2.06 & 2.30 & $2.66 \mathrm{E}-06$ & $1.89 \mathrm{E}-08$ \\
\hline SB13-11 & upper & 7.31 & -1.07 & 0.103 & 2.10 & 2.35 & $5.43 \mathrm{E}-06$ & $6.50 \mathrm{E}-08$ \\
\hline SB13-12 & upper & 8.08 & -0.30 & 0.102 & 2.10 & 2.34 & $3.66 \mathrm{E}-06$ & 4.31E-09 \\
\hline \multicolumn{9}{|c|}{ Transect SB-14 } \\
\hline SB14-1 & pumice & 0.61 & -7.85 & 0.490 & 1.21 & 2.38 & $1.00 \mathrm{E}-04$ & $3.08 \mathrm{E}-05$ \\
\hline SB14-2 & lower & 0.91 & -7.54 & 0.425 & 1.31 & 2.27 & $1.31 \mathrm{E}-04$ & $1.81 \mathrm{E}-03$ \\
\hline SB14-3 & lower & 1.52 & -6.93 & 0.419 & 1.31 & 2.25 & $4.16 \mathrm{E}-04$ & 2.63E-03 \\
\hline SB14-4 & lower & 2.13 & -6.32 & 0.399 & 1.38 & 2.29 & $1.49 \mathrm{E}-04$ & $1.22 \mathrm{E}-04$ \\
\hline SB14-5 & lower & 2.90 & -5.56 & 0.428 & 1.31 & 2.29 & $2.50 \mathrm{E}-04$ & $1.56 \mathrm{E}-03$ \\
\hline SB14-6 & lower & 3.35 & -5.11 & 0.414 & 1.40 & 2.38 & $2.39 \mathrm{E}-04$ & $1.46 \mathrm{E}-03$ \\
\hline SB14-7 & lower & 4.11 & -4.34 & 0.379 & 1.43 & 2.30 & $5.94 \mathrm{E}-05$ & 6.63E-06 \\
\hline SB14-8 & lower & 4.57 & -3.89 & 0.343 & 1.54 & 2.34 & $1.06 \mathrm{E}-05$ & $6.28 \mathrm{E}-05$ \\
\hline SB14-9 & upper & 5.94 & -2.51 & 0.171 & 1.85 & 2.24 & $2.44 \mathrm{E}-06$ & - \\
\hline SB14-10 & upper & 7.62 & -0.84 & 0.122 & 2.06 & 2.35 & $5.00 \mathrm{E}-06$ & -- \\
\hline SB14-11 & upper & 8.08 & -0.38 & 0.107 & 2.08 & 2.33 & $5.47 \mathrm{E}-06$ & 5.17E-09 \\
\hline SB14-12 & columnar & 8.84 & 0.38 & 0.089 & 2.12 & 2.33 & $5.47 \mathrm{E}-06$ & -- \\
\hline \multicolumn{9}{|c|}{ Transect SB-15 } \\
\hline SB15-1 & pumice & 0.61 & -8.84 & 0.436 & 1.33 & 2.36 & 8.65E-05 & 5.13E-05 \\
\hline SB15-2 & lower & 0.91 & -8.53 & 0.395 & 1.37 & 2.27 & $1.74 \mathrm{E}-04$ & $2.95 \mathrm{E}-04$ \\
\hline SB15-3 & lower & 1.68 & -7.77 & 0.427 & 1.29 & 2.26 & $3.55 \mathrm{E}-04$ & $1.11 \mathrm{E}-03$ \\
\hline SB15-4 & lower & 2.13 & -7.31 & 0.421 & 1.32 & 2.29 & $2.33 \mathrm{E}-04$ & 4.40E-04 \\
\hline SB15-5 & lower & 3.05 & -6.40 & 0.405 & 1.37 & 2.31 & $1.06 \mathrm{E}-04$ & $1.34 \mathrm{E}-04$ \\
\hline SB15-6 & lower & 3.81 & -5.64 & 0.406 & 1.38 & 2.33 & $9.59 \mathrm{E}-05$ & $5.58 \mathrm{E}-05$ \\
\hline SB15-7 & lower & 4.27 & -5.18 & 0.352 & 1.53 & 2.36 & $9.43 \mathrm{E}-06$ & 2.33E-06 \\
\hline SB15-8 & upper & 5.79 & -3.66 & 0.232 & 1.77 & 2.31 & $4.78 \mathrm{E}-06$ & 2.03E-07 \\
\hline SB15-9 & upper & 6.55 & -2.90 & 0.176 & 1.91 & 2.32 & $2.16 \mathrm{E}-06$ & $8.19 \mathrm{E}-08$ \\
\hline SB15-10 & upper & 7.01 & -2.44 & 0.128 & 2.04 & 2.34 & $1.82 \mathrm{E}-06$ & $3.49 \mathrm{E}-08$ \\
\hline SB15-11 & upper & 8.38 & -1.07 & 0.103 & 2.13 & 2.37 & $5.45 \mathrm{E}-06$ & $3.71 \mathrm{E}-08$ \\
\hline \multicolumn{9}{|c|}{ Transect SB-16 } \\
\hline SB16-1 & pumice & 1.37 & -9.60 & 0.341 & 1.54 & 2.34 & $1.17 \mathrm{E}-04$ & $2.42 \mathrm{E}-03$ \\
\hline SB16-2 & lower & 1.98 & -8.99 & 0.419 & 1.30 & 2.24 & $2.43 \mathrm{E}-04$ & $7.79 \mathrm{E}-04$ \\
\hline SB16-3 & lower & 2.59 & -8.38 & 0.422 & 1.32 & 2.29 & $1.96 \mathrm{E}-04$ & $3.03 \mathrm{E}-04$ \\
\hline SB16-4 & lower & 3.66 & -7.31 & 0.425 & 1.31 & 2.28 & $3.07 \mathrm{E}-04$ & $5.07 \mathrm{E}-04$ \\
\hline SB16-5 & lower & 3.81 & -7.16 & 0.411 & 1.35 & 2.29 & $1.09 \mathrm{E}-04$ & $3.56 \mathrm{E}-04$ \\
\hline SB16-6 & lower & 4.42 & -6.55 & 0.427 & 1.31 & 2.29 & $2.47 \mathrm{E}-04$ & $1.03 \mathrm{E}-03$ \\
\hline SB16-7 & lower & 5.18 & -5.79 & 0.436 & 1.30 & 2.31 & $3.59 \mathrm{E}-04$ & $1.33 \mathrm{E}-03$ \\
\hline SB16-8 & lower & 5.64 & -5.33 & 0.415 & 1.36 & 2.32 & $1.70 \mathrm{E}-04$ & $3.41 \mathrm{E}-04$ \\
\hline
\end{tabular}


Table 4. Physical and hydrologic properties of outcrop samples from Yucca Mountain, Nevada, determined by relativehumidity oven drying--Continued

\begin{tabular}{|c|c|c|c|c|c|c|c|c|}
\hline $\begin{array}{c}\text { Sample } \\
\text { Identifi- } \\
\text { cation }\end{array}$ & Subunit & $\begin{array}{c}\text { Height } \\
\text { above } \\
\text { base of } \\
\text { pumice } \\
\text { (meters) }\end{array}$ & $\begin{array}{c}\text { Depth } \\
\text { below } \\
\text { columnar } \\
\text { unit } \\
\text { (meters) }\end{array}$ & $\begin{array}{c}\text { Porosity } \\
\text { (fraction) }\end{array}$ & $\begin{array}{c}\text { Bulk } \\
\text { density } \\
\left(\mathrm{g} / \mathrm{cm}^{3}\right)\end{array}$ & $\begin{array}{l}\text { Particle } \\
\text { density } \\
\left(\mathrm{g} / \mathrm{cm}^{3}\right)\end{array}$ & $\begin{array}{l}\text { Sorptivity } \\
(\sqrt{\mathrm{cm} /}) \\
(\sqrt{\mathrm{sec}})\end{array}$ & $\begin{array}{c}\text { Saturated } \\
\text { hydraulic } \\
\text { conductivity } \\
\text { (m/sec) }\end{array}$ \\
\hline \multicolumn{9}{|c|}{ Transect SB-16-Continued } \\
\hline SB16-9 & lower & 6.55 & -4.42 & 0.373 & 1.48 & 2.36 & $5.82 \mathrm{E}-05$ & 3.89E-05 \\
\hline SB16-10 & upper & 7.16 & -3.81 & 0.336 & 1.56 & 2.35 & $1.23 \mathrm{E}-05$ & $1.85 \mathrm{E}-06$ \\
\hline SB16-11 & upper & 7.77 & -3.20 & 0.236 & 1.80 & 2.35 & $1.01 \mathrm{E}-05$ & $1.03 \mathrm{E}-06$ \\
\hline SB16-12 & upper & 8.99 & -1.98 & 0.169 & 1.94 & 2.34 & $7.79 \mathrm{E}-06$ & $2.86 \mathrm{E}-06$ \\
\hline SB16-13 & upper & 9.30 & -1.68 & 0.152 & 1.99 & 2.35 & $6.79 \mathrm{E}-06$ & $1.50 \mathrm{E}-07$ \\
\hline SB16-14 & upper & 10.06 & -0.91 & 0.100 & 2.12 & 2.36 & 4.32E-06 & $1.99 \mathrm{E}-08$ \\
\hline SB16-15 & upper & 10.52 & -0.46 & 0.107 & 2.13 & 2.38 & $5.47 \mathrm{E}-06$ & $2.09 \mathrm{E}-07$ \\
\hline \multicolumn{9}{|c|}{ Transect SB17 } \\
\hline SB17-1 & pumice & 0.30 & -9.91 & 0.596 & 0.94 & 2.32 & $1.03 \mathrm{E}-03$ & $1.08 \mathrm{E}-02$ \\
\hline SB17-2 & pumice & 0.91 & -9.30 & 0.448 & 1.31 & 2.37 & $2.97 \mathrm{E}-04$ & $1.25 E-03$ \\
\hline SB17-3 & lower & 1.52 & -8.69 & 0.489 & 1.18 & 2.31 & $3.71 \mathrm{E}-04$ & $5.57 \mathrm{E}-04$ \\
\hline ȘB17-4 & lower & 2.74 & -7.47 & 0.433 & 1.31 & 2.31 & $3.64 \mathrm{E}-04$ & $9.95 \mathrm{E}-04$ \\
\hline SB17-5 & lower & 3.35 & -6.86 & 0.416 & 1.35 & 2.31 & $1.62 \mathrm{E}-04$ & $4.96 \mathrm{E}-04$ \\
\hline SB17-6 & lower & 4.11 & -6.10 & 0.389 & 1.41 & 2.31 & $1.88 \mathrm{E}-04$ & $7.61 \mathrm{E}-05$ \\
\hline SB $17-7$ & upper & 4.88 & -5.33 & 0.382 & 1.44 & 2.33 & $5.35 \mathrm{E}-05$ & $6.22 \mathrm{E}-05$ \\
\hline SB17-8 & upper & 5.64 & -4.57 & 0.321 & 1.59 & 2.34 & $4.10 \mathrm{E}-06$ & $2.05 \mathrm{E}-06$ \\
\hline SB 17-9 & upper & 7.62 & -2.59 & 0.200 & 1.88 & 2.35 & $6.06 \mathrm{E}-06$ & $2.01 \mathrm{E}-07$ \\
\hline SB17-10 & upper & 9.45 & -0.76 & 0.114 & 2.09 & 2.36 & $3.28 \mathrm{E}-06$ & $3.63 \mathrm{E}-08$ \\
\hline \multicolumn{9}{|c|}{ Transect SB-18 } \\
\hline SB18-1 & pumice & 0.30 & -9.60 & 0.582 & 0.98 & 2.33 & $4.56 \mathrm{E}-04$ & $2.30 \mathrm{E}-03$ \\
\hline SB18-2 & lower & 2.44 & -7.47 & 0.419 & 1.31 & 2.25 & 2.01E-04 & $2.60 \mathrm{E}-04$ \\
\hline SB18-3 & lower & 3.20 & -6.71 & 0.417 & 1.30 & 2.23 & $2.20 \mathrm{E}-04$ & 2.83E-04 \\
\hline SB18-4 & lower & 3.66 & -6.25 & 0.418 & 1.34 & 2.30 & $2.55 \mathrm{E}-04$ & $5.96 \mathrm{E}-04$ \\
\hline SB18-5 & lower & 3.96 & -5.94 & 0.414 & 1.33 & 2.28 & $1.85 \mathrm{E}-04$ & $1.15 \mathrm{E}-03$ \\
\hline SB18-6 & lower & 4.57 & -5.33 & 0.419 & 1.34 & 2.31 & $1.45 \mathrm{E}-04$ & $1.77 \mathrm{E}-04$ \\
\hline SB18-7 & upper & 5.33 & -4.57 & 0.377 & 1.46 & 2.34 & $6.33 \mathrm{E}-05$ & $1.86 \mathrm{E}-05$ \\
\hline SB18-8 & upper & 6.10 & -3.81 & 0.326 & 1.58 & 2.34 & $9.55 \mathrm{E}-06$ & 2.79E-07 \\
\hline SB18-9 & upper & 7.31 & -2.59 & 0.229 & 1.80 & 2.34 & $5.42 \mathrm{E}-06$ & $1.12 \mathrm{E}-07$ \\
\hline SB18-10 & upper & 9.14 & -0.76 & 0.112 & 2.10 & 2.36 & $4.68 \mathrm{E}-06$ & $1.90 \mathrm{E}-08$ \\
\hline \multicolumn{9}{|c|}{ Transect SB-19 } \\
\hline SB19-1 & pumice & 0.30 & -9.60 & 0.603 & 0.93 & 2.34 & 3.73E-04 & $5.40 \mathrm{E}-04$ \\
\hline SB 19-2 & pumice & 0.91 & -8.99 & 0.488 & 1.22 & 2.39 & $2.51 \mathrm{E}-04$ & $1.05 \mathrm{E}-03$ \\
\hline SB19-3 & lower & 1.98 & -7.92 & 0.431 & 1.32 & 2.32 & 4.13E-04 & $2.41 \mathrm{E}-03$ \\
\hline SB19-4 & lower & 2.44 & -7.47 & 0.427 & 1.32 & 2.31 & $1.40 \mathrm{E}-04$ & 7.39E-04 \\
\hline SB19-5 & lower & 3.05 & -6.86 & 0.462 & 1.26 & 2.35 & $2.49 \mathrm{E}-04$ & $2.22 \mathrm{E}-04$ \\
\hline SB19-6 & lower & 3.51 & -6.40 & 0.461 & 1.26 & 2.34 & $1.04 \mathrm{E}-04$ & $1.70 \mathrm{E}-04$ \\
\hline SB19-7 & lower & 4.27 & -5.64 & 0.444 & 1.31 & 2.36 & 7.34E-05 & 2.09E-05 \\
\hline SB19-8 & upper & 5.33 & -4.57 & 0.338 & 1.56 & 2.36 & $1.26 \mathrm{E}-05$ & $6.00 \mathrm{E}-07$ \\
\hline SB 19-9 & upper & 6.10 & -3.81 & 0.254 & 1.75 & 2.35 & $4.40 \mathrm{E}-06$ & $9.45 \mathrm{E}-08$ \\
\hline SB19-10 & upper & 6.86 & -3.05 & 0.202 & 1.89 & 2.37 & 3.47E-06 & 5.37E-08 \\
\hline
\end{tabular}


Table 4. Physical and hydrologic properties of outcrop samples from Yucca Mountain, Nevada, determined by relativehumidity oven drying--Continued

\begin{tabular}{|c|c|c|c|c|c|c|c|c|}
\hline $\begin{array}{l}\text { Sample } \\
\text { Identifi- } \\
\text { cation }\end{array}$ & Subunit & $\begin{array}{l}\text { Height } \\
\text { above } \\
\text { base of } \\
\text { pumice } \\
\text { (meters) }\end{array}$ & $\begin{array}{c}\text { Depth } \\
\text { below } \\
\text { columnar } \\
\text { unit } \\
\text { (meters) }\end{array}$ & $\begin{array}{l}\text { Porosity } \\
\text { (fraction) }\end{array}$ & $\begin{array}{c}\text { Bulk } \\
\text { density } \\
\left(\mathrm{g} / \mathrm{cm}^{3}\right)\end{array}$ & $\begin{array}{l}\text { Particle } \\
\text { density } \\
\left(\mathrm{g} / \mathrm{cm}^{3}\right)\end{array}$ & $\begin{array}{l}\text { Sorptivity } \\
\text { (cm) } \\
(\sqrt{\sec })\end{array}$ & $\begin{array}{c}\text { Saturated } \\
\text { hydraulic } \\
\text { conductivity } \\
\text { (m/sec) }\end{array}$ \\
\hline \multicolumn{9}{|c|}{ Transect SB-20 } \\
\hline SB20-1 & pumice & 0.30 & -8.69 & 0.578 & 0.99 & 2.34 & $2.49 \mathrm{E}-04$ & $3.55 \mathrm{E}-03$ \\
\hline SB20-2 & lower & 1.37 & -7.62 & 0.405 & 1.34 & 2.26 & $5.82 \mathrm{E}-04$ & $2.58 \mathrm{E}-03$ \\
\hline SB20-3 & lower & 1.98 & -7.01 & 0.396 & 1.38 & 2.28 & $3.22 \mathrm{E}-04$ & 2.29E-04 \\
\hline SB20-4 & lower & 2.74 & -6.25 & 0.402 & 1.36 & 2.28 & 4.33E-04 & $1.98 \mathrm{E}-03$ \\
\hline SB20-5 & lower & 3.20 & -5.79 & 0.391 & 1.42 & 2.33 & $1.68 \mathrm{E}-04$ & $1.25 \mathrm{E}-04$ \\
\hline SB20-6 & upper & 3.66 & -5.33 & 0.389 & 1.43 & 2.33 & $1.34 \mathrm{E}-04$ & $6.25 \mathrm{E}-05$ \\
\hline SB20-7 & upper & 4.11 & -4.88 & 0.373 & 1.47 & 2.34 & $1.53 \mathrm{E}-04$ & $2.80 \mathrm{E}-05$ \\
\hline SB20-8 & upper & 4.88 & -4.11 & 0.335 & 1.57 & 2.36 & $1.37 \mathrm{E}-05$ & $1.90 \mathrm{E}-06$ \\
\hline SB20-9 & upper & 5.49 & -3.51 & 0.245 & 1.80 & 2.38 & $1.05 \mathrm{E}-05$ & $1.50 \mathrm{E}-07$ \\
\hline SB20-10 & upper & 8.38 & -0.61 & 0.100 & 2.15 & 2.39 & $3.45 \mathrm{E}-06$ & $1.50 \mathrm{E}-08$ \\
\hline \multicolumn{9}{|c|}{ Transect SB-21 } \\
\hline SB21-1 & pumice & 0.30 & -9.30 & 0.585 & 0.98 & 2.36 & $4.44 \mathrm{E}-04$ & 8.55E-03 \\
\hline SB21-2 & pumice & 0.91 & -8.69 & 0.468 & 1.25 & 2.34 & $3.69 \mathrm{E}-04$ & $1.37 \mathrm{E}-03$ \\
\hline SB21-3 & lower & 2.13 & -7.47 & 0.412 & 1.34 & 2.29 & 3.77E-04 & $7.78 \mathrm{E}-04$ \\
\hline SB21-4 & lower & 2.74 & -6.86 & 0.402 & 1.36 & 2.28 & $3.02 \mathrm{E}-04$ & 7.29E-04 \\
\hline SB21-5 & lower & 3.35 & -6.25 & 0.432 & 1.32 & 2.32 & $2.25 \mathrm{E}-04$ & $6.98 \mathrm{E}-04$ \\
\hline SB21-6 & upper & 3.96 & -5.64 & 0.445 & 1.30 & 2.34 & $1.37 \mathrm{E}-04$ & $7.36 \mathrm{E}-04$ \\
\hline SB21-7 & upper & 4.27 & -5.33 & 0.425 & 1.34 & 2.33 & $2.90 \mathrm{E}-04$ & $1.19 \mathrm{E}-04$ \\
\hline SB21-8 & upper & 4.72 & -4.88 & 0.345 & 1.51 & 2.30 & $7.69 \mathrm{E}-05$ & $6.01 \mathrm{E}-06$ \\
\hline SB21-9 & upper & 5.64 & -3.96 & 0.297 & 1.62 & 2.30 & $8.36 \mathrm{E}-06$ & $5.12 \mathrm{E}-07$ \\
\hline SB21-10 & upper & 6.40 & -3.20 & 0.206 & 1.81 & 2.28 & $5.86 \mathrm{E}-06$ & $1.67 \mathrm{E}-07$ \\
\hline SB21-11 & upper & 7.16 & -2.44 & 0.187 & 1.93 & 2.38 & $1.55 \mathrm{E}-05$ & $9.90 \mathrm{E}-08$ \\
\hline SB21-12 & upper & 7.77 & -1.83 & 0.157 & 1.99 & 2.36 & $5.81 \mathrm{E}-06$ & -- \\
\hline SB21-13 & upper & 8.69 & -0.91 & 0.111 & 2.11 & 2.38 & $5.53 \mathrm{E}-06$ & $2.28 \mathrm{E}-08$ \\
\hline SB21-14 & upper & 8.84 & -0.76 & 0.123 & 2.07 & 2.36 & 8.86E-06 & $3.56 \mathrm{E}-07$ \\
\hline SB21-15 & upper & 9.45 & -0.15 & 0.173 & 1.97 & 2.39 & $1.52 \mathrm{E}-05$ & $2.23 \mathrm{E}-08$ \\
\hline \multicolumn{9}{|c|}{ Transect SB-22 } \\
\hline SB22-11 & pumice & 0.30 & -8.53 & 0.596 & 0.95 & 2.35 & - & -- \\
\hline SB22-12 & lower & 1.52 & -7.31 & 0.416 & 1.34 & 2.29 & $7.38 \mathrm{E}-04$ & $3.83 \mathrm{E}-04$ \\
\hline SB22-13 & lower & 1.98 & -6.86 & 0.382 & 1.41 & 2.27 & $6.08 \mathrm{E}-05$ & $1.35 \mathrm{E}-03$ \\
\hline SB22-14 & lower & 2.44 & -6.40 & 0.399 & 1.35 & 2.25 & - & $7.01 \mathrm{E}-03$ \\
\hline SB22-15 & lower & 3.05 & -5.79 & 0.413 & 1.33 & 2.27 & -- & $2.87 \mathrm{E}-03$ \\
\hline SB22-16 & lower & 3.66 & -5.18 & 0.400 & 1.37 & 2.29 & $1.97 \mathrm{E}-04$ & $8.86 \mathrm{E}-05$ \\
\hline SB22-17 & lower & 4.11 & -4.72 & 0.384 & 1.42 & 2.30 & $2.46 \mathrm{E}-05$ & $1.27 \mathrm{E}-05$ \\
\hline SB22-18 & lower & 4.57 & -4.27 & 0.332 & 1.55 & 2.32 & $5.95 \mathrm{E}-06$ & $2.13 \mathrm{E}-06$ \\
\hline SB22-19 & upper & 5.49 & -3.35 & 0.333 & 1.57 & 2.35 & 5.59E-06 & $3.80 \mathrm{E}-06$ \\
\hline SB22-20 & upper & 5.79 & -3.05 & 0.224 & 1.76 & 2.27 & -- & 4.12E-08 \\
\hline SB22-21 & upper & 6.25 & -2.59 & 0.184 & 1.87 & 2.29 & - & $1.22 \mathrm{E}-07$ \\
\hline SB22-22 & upper & 6.86 & -1.98 & 0.152 & 1.98 & 2.34 & -- & $2.07 \mathrm{E}-08$ \\
\hline SB22-23 & upper & 7.31 & -1.52 & 0.115 & 2.08 & 2.35 & -- & $2.61 \mathrm{E}-08$ \\
\hline
\end{tabular}


Table 4. Physical and hydrologic properties of outcrop samples from Yucca Mountain, Nevada, determined by relativehumidity oven drying--Continued

\begin{tabular}{|c|c|c|c|c|c|c|c|c|}
\hline $\begin{array}{l}\text { Sample } \\
\text { Identifi- } \\
\text { cation }\end{array}$ & Subunit & $\begin{array}{l}\text { Height } \\
\text { above } \\
\text { base of } \\
\text { pumice } \\
\text { (meters) }\end{array}$ & $\begin{array}{c}\text { Depth } \\
\text { below } \\
\text { columnar } \\
\text { unit } \\
\text { (meters) }\end{array}$ & $\begin{array}{l}\text { Porosity } \\
\text { (fraction) }\end{array}$ & $\begin{array}{c}\text { Bulk } \\
\text { density } \\
\left(\mathrm{g} / \mathrm{cm}^{3}\right)\end{array}$ & $\begin{array}{l}\text { Particle } \\
\text { density } \\
\left(\mathrm{g} / \mathrm{cm}^{3}\right)\end{array}$ & $\begin{array}{l}\text { Sorptivity } \\
\text { (cm) } \\
(\sqrt{\sec })\end{array}$ & $\begin{array}{c}\text { Saturated } \\
\text { hydraulic } \\
\text { conductivity } \\
\text { (m/sec) }\end{array}$ \\
\hline \multicolumn{9}{|c|}{ Transect SB-23 } \\
\hline SB23-1 & pumice & 0.30 & -9.91 & 0.582 & 0.97 & 2.32 & $7.50 \mathrm{E}-04$ & $1.29 \mathrm{E}-02$ \\
\hline SB23-2 & pumice & 1.07 & -9.14 & 0.420 & 1.35 & 2.33 & 2.13E-04 & $8.68 \mathrm{E}-04$ \\
\hline SB23-3 & lower & 1.22 & -8.99 & 0.420 & 1.32 & 2.28 & $2.86 \mathrm{E}-04$ & $6.48 \mathrm{E}-04$ \\
\hline SB23-4 & lower & 2.29 & -7.92 & 0.435 & 1.31 & 2.32 & $4.85 \mathrm{E}-04$ & $2.65 \mathrm{E}-03$ \\
\hline SB23-5 & lower & 2.74 & -7.47 & 0.415 & 1.34 & 2.28 & 4.44E-04 & $9.48 \mathrm{E}-04$ \\
\hline SB23-6 & lower & 3.66 & -6.55 & 0.429 & 1.31 & 2.30 & 4.38E-04 & $1.20 \mathrm{E}-03$ \\
\hline SB23-7 & lower & 4.27 & -5.94 & 0.385 & 1.43 & 2.32 & $1.07 \mathrm{E}-04$ & 4.32E-05 \\
\hline SB23-8 & lower & 4.88 & -5.33 & 0.350 & 1.52 & 2.34 & $7.14 \mathrm{E}-05$ & $2.04 \mathrm{E}-05$ \\
\hline SB23-9 & upper & 6.71 & -3.51 & 0.215 & 1.83 & 2.34 & $6.38 \mathrm{E}-06$ & $2.08 \mathrm{E}-08$ \\
\hline SB23-10 & upper & 8.08 & -2.13 & 0.140 & 2.00 & 2.33 & $5.45 \mathrm{E}-06$ & $7.10 \mathrm{E}-08$ \\
\hline SB23-11 & upper & 9.14 & -1.07 & 0.111 & 2.08 & 2.33 & $5.28 \mathrm{E}-06$ & $1.01 \mathrm{E}-07$ \\
\hline SB23-12 & upper & 9.91 & -0.30 & 0.104 & 2.12 & 2.36 & $4.76 \mathrm{E}-06$ & -- \\
\hline SB23-13 & columnar & 10.67 & 0.46 & 0.141 & 2.02 & 2.35 & $1.03 \mathrm{E}-05$ & $7.28 \mathrm{E}-08$ \\
\hline \multicolumn{9}{|c|}{ Transect SB-24 } \\
\hline SB24-1 & pumice & 0.30 & -9.52 & 0.555 & 1.03 & 2.32 & $6.85 \mathrm{E}-04$ & $6.87 \mathrm{E}-03$ \\
\hline SB24-2 & lower & 1.83 & -8.00 & 0.415 & 1.33 & 2.27 & $1.75 \mathrm{E}-04$ & $6.10 \mathrm{E}-04$ \\
\hline SB24-3 & lower & 2.59 & -7.24 & 0.438 & 1.29 & 2.29 & $2.20 \mathrm{E}-04$ & 2.61E-04 \\
\hline SB24-4A & lower & 3.20 & -6.63 & 0.438 & 1.33 & 2.37 & $1.76 \mathrm{E}-04$ & $1.73 \mathrm{E}-04$ \\
\hline SB24-4B & lower & 4.11 & -5.71 & 0.396 & 1.40 & 2.32 & - & -- \\
\hline SB24-5 & lower & 4.57 & -5.26 & 0.390 & 1.42 & 2.33 & $5.88 \mathrm{E}-05$ & $4.05 \mathrm{E}-05$ \\
\hline SB24-6 & lower & 5.18 & -4.65 & 0.241 & 1.78 & 2.35 & $1.46 \mathrm{E}-05$ & $1.99 \mathrm{E}-06$ \\
\hline SB24-7 & upper & 6.71 & -3.12 & 0.114 & 1.96 & 2.21 & $5.52 \mathrm{E}-06$ & -- \\
\hline SB24-8 & upper & 7.31 & -2.51 & 0.143 & 1.98 & 2.31 & $3.73 E-06$ & $9.43 \mathrm{E}-09$ \\
\hline SB24-9 & upper & 7.92 & -1.90 & 0.117 & 2.05 & 2.32 & $3.46 \mathrm{E}-06$ & 8.99E-09 \\
\hline SB24-10 & upper & 8.84 & -0.99 & 0.115 & 2.10 & 2.38 & $5.74 \mathrm{E}-06$ & -- \\
\hline SB24-11 & upper & 9.75 & -0.08 & 0.134 & 2.08 & 2.40 & $5.66 \mathrm{E}-06$ & $5.98 \mathrm{E}-09$ \\
\hline \multicolumn{9}{|c|}{ Transect SB-25 } \\
\hline SB25-1 & lower & 1.98 & -7.92 & 0.399 & 1.36 & 2.27 & $2.90 \mathrm{E}-04$ & $2.35 \mathrm{E}-04$ \\
\hline SB25-2 & lower & 2.74 & -7.16 & 0.432 & 1.29 & 2.26 & $1.25 \mathrm{E}-04$ & $4.96 \mathrm{E}-05$ \\
\hline SB25-3 & lower & 3.51 & -6.40 & 0.308 & 1.59 & 2.30 & $2.40 \mathrm{E}-05$ & $9.63 \mathrm{E}-06$ \\
\hline SB25-4 & lower & 4.27 & -5.64 & 0.315 & 1.57 & 2.29 & $6.78 \mathrm{E}-05$ & $3.58 \mathrm{E}-05$ \\
\hline SB25-5 & lower & 5.03 & -4.88 & 0.285 & 1.64 & 2.30 & $9.06 \mathrm{E}-06$ & $1.44 \mathrm{E}-06$ \\
\hline SB25-6 & lower & 5.64 & -4.27 & 0.201 & 1.87 & 2.34 & 7.77E-06 & $3.23 \mathrm{E}-06$ \\
\hline SB25-7 & upper & 6.86 & -3.05 & 0.123 & 2.00 & 2.28 & 4.33E-06 & $1.61 \mathrm{E}-08$ \\
\hline SB25-8 & upper & 7.77 & -2.13 & 0.115 & 2.08 & 2.35 & $3.73 \mathrm{E}-06$ & $5.78 \mathrm{E}-09$ \\
\hline SB25-9 & upper & 8.99 & -0.91 & 0.096 & 2.11 & 2.34 & $1.36 \mathrm{E}-06$ & $3.28 \mathrm{E}-08$ \\
\hline SB25-10 & upper & 9.30 & -0.61 & 0.061 & 2.17 & 2.31 & $2.05 \mathrm{E}-06$ & $9.43 \mathrm{E}-08$ \\
\hline
\end{tabular}


Table 4. Physical and hydrologic properties of outcrop samples from Yucca Mountain, Nevada, determined by relativehumidity oven drying--Continued

\begin{tabular}{|c|c|c|c|c|c|c|c|c|}
\hline $\begin{array}{l}\text { Sample } \\
\text { Identifi- } \\
\text { cation }\end{array}$ & Subunit & $\begin{array}{l}\text { Height } \\
\text { above } \\
\text { base of } \\
\text { pumice } \\
\text { (meters) }\end{array}$ & $\begin{array}{c}\text { Depth } \\
\text { below } \\
\text { columnar } \\
\text { unit } \\
\text { (meters) }\end{array}$ & $\begin{array}{l}\text { Porosity } \\
\text { (fraction) }\end{array}$ & $\begin{array}{c}\text { Bulk } \\
\text { density } \\
\left(\mathrm{g} / \mathrm{cm}^{3}\right)\end{array}$ & $\begin{array}{l}\text { Particlè } \\
\text { density } \\
\left(\mathrm{g} / \mathrm{cm}^{3}\right)\end{array}$ & $\begin{array}{l}\text { Sorptivity } \\
\text { (cm) } \\
(\sqrt{\mathrm{sec}})\end{array}$ & $\begin{array}{c}\text { Saturated } \\
\text { hydraulic } \\
\text { conductivity } \\
\text { (m/sec) }\end{array}$ \\
\hline \multicolumn{9}{|c|}{ Transect SB-26 } \\
\hline SB26-1 & pumice & 0.30 & -10.44 & 0.556 & 1.03 & 2.32 & $3.89 \mathrm{E}-04$ & 3.77E-03 \\
\hline SB26-2 & lower & 1.37 & -9.37 & 0.398 & 1.39 & 2.30 & $3.08 \mathrm{E}-04$ & $7.90 \mathrm{E}-04$ \\
\hline SB26-4 & lower & 2.13 & -8.61 & 0.405 & 1.35 & 2.28 & $3.80 \mathrm{E}-04$ & $5.64 \mathrm{E}-04$ \\
\hline SB26-5 & lower & 2.59 & -8.15 & 0.424 & 1.32 & 2.29 & $5.29 \mathrm{E}-04$ & 2.65E-03 \\
\hline SB26-6 & lower & 3.35 & -7.39 & 0.429 & 1.30 & 2.28 & 4.84E-04 & $1.06 \mathrm{E}-03$ \\
\hline SB26-7 & upper & 4.11 & -6.63 & 0.412 & 1.33 & 2.27 & 4.02E-04 & $3.08 \mathrm{E}-04$ \\
\hline SB26-8 & upper & 4.57 & -6.17 & 0.368 & 1.46 & 2.31 & $5.74 \mathrm{E}-05$ & $1.03 \mathrm{E}-04$ \\
\hline SB26-9 & upper & 5.18 & -5.56 & 0.340 & 1.51 & 2.29 & $1.04 \mathrm{E}-04$ & $3.55 \mathrm{E}-05$ \\
\hline SB26-10 & upper & 6.10 & -4.65 & 0.284 & 1.66 & 2.31 & 7.07E-06 & $2.36 \mathrm{E}-06$ \\
\hline SB26-11 & upper & 6.40 & -4.34 & 0.218 & 1.77 & 2.26 & $6.40 \mathrm{E}-06$ & 2.31E-07 \\
\hline SB26-12 & upper & 7.01 & -3.73 & 0.208 & 1.88 & 2.37 & $1.35 \mathrm{E}-05$ & 3.34E-07 \\
\hline SB26-13 & upper & 7.62 & -3.12 & 0.158 & 1.99 & 2.37 & $6.38 \mathrm{E}-06$ & 2.70E-07 \\
\hline SB26-14 & upper & 8.08 & -2.67 & 0.116 & 2.07 & 2.34 & -- & $1.61 \mathrm{E}-07$ \\
\hline SB26-15 & upper & 8.69 & -2.06 & 0.087 & 2.14 & 2.34 & 4.54E-06 & $9.47 \mathrm{E}-09$ \\
\hline SB26-16 & upper & 9.75 & -0.99 & 0.089 & 2.11 & 2.32 & 4.87E-06 & $2.62 \mathrm{E}-08$ \\
\hline SB26-17 & upper & 10.67 & -0.08 & 0.086 & 2.17 & 2.37 & $7.03 \mathrm{E}-06$ & 3.32E-08 \\
\hline
\end{tabular}

